University at Buffalo School of Law

Digital Commons @ University at Buffalo School of Law

$1-1-2015$

\title{
From the Picket Line to the Courtroom: A Labor Organizing Privilege to Protect Workers
}

Nicole Hallett

University at Buffalo School of Law

Follow this and additional works at: https://digitalcommons.law.buffalo.edu/journal_articles

Part of the Labor and Employment Law Commons

\section{Recommended Citation}

Nicole Hallett, From the Picket Line to the Courtroom: A Labor Organizing Privilege to Protect Workers, 39 N.Y.U. Rev. L. \& Soc. Change 475 (2015).

Available at: https://digitalcommons.law.buffalo.edu/journal_articles/898

This Article is brought to you for free and open access by the Faculty Scholarship at Digital Commons @ University at Buffalo School of Law. It has been accepted for inclusion in Journal Articles by an authorized administrator of Digital Commons @ University at Buffalo School of Law. For more information, please contact lawscholar@buffalo.edu. 


\title{
FROM THE PICKET LINE TO THE COURTROOM: A LABOR ORGANIZING PRIVILEGE TO PROTECT WORKERS
}

\author{
NICOLE HALLETT ${ }^{\infty}$
}

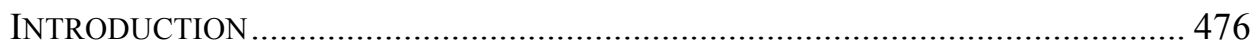

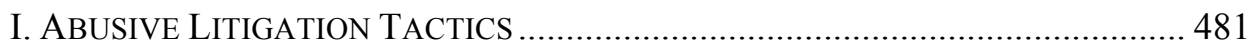

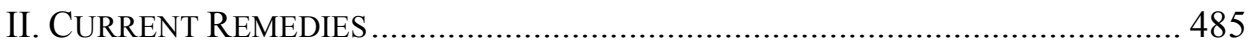

A. NLRB Unfair Labor Practice Charge …................................................... 485

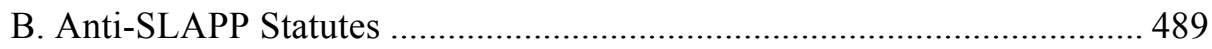

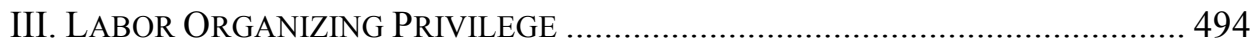

A. Theoretical Justifications for Evidentiary Privileges.............................. 496

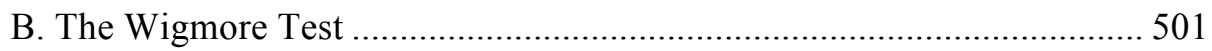

1. The Communications Were Made in Confidence ................................. 501

2. The Element of Confidentiality Is Essential to Maintain the Parties'

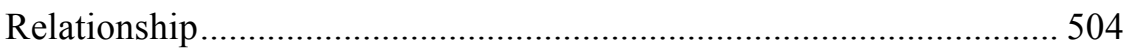

3. There Is a Community Need to Sedulously Foster the Relationship.... 506

4. The Harm to the Relationship Caused by the Disclosure Would

Exceed Any Benefit from the Correct Disposal of the Litigation........ 508

C. Humanistic and Egalitarian Justifications................................................. 509

D. Constitutional Arguments ................................................................. 511

E. Existing Labor-Related Evidentiary Privileges....................................... 515

1. Union Representative Privilege ........................................................ 515

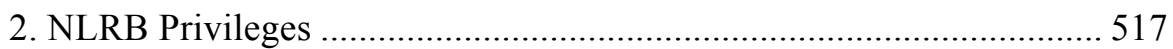

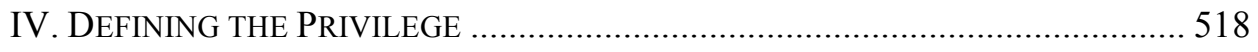

A. Absolute vs. Qualified Privilege ........................................................... 519

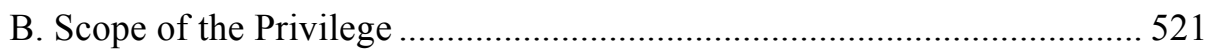

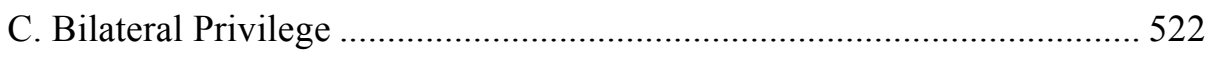

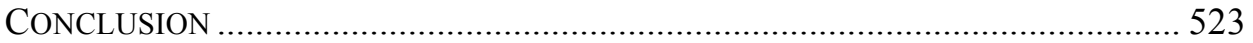

$\infty$ Robert M. Cover Fellow and Associate Research Scholar in Law at Yale Law School; J.D., Yale Law School; MSc, University of Oxford; B.A., DePauw University. The author thanks Michael Wishnie, Muneer Ahmad, Harold Koh, Raja Raghunath, Hina Shah, Ingrid Easley, Jon Bauer, Daniel Richman, Charlotte Garden, and the participants at the work-in-progress session of the AALS Clinical Conference for their guidance and comments on various drafts of this article. 


\section{INTRODUCTION}

Income inequality in the United States has reached unprecedented levels. ${ }^{1}$ Wages for low- and middle-income people have stagnated in the past thirty years, while the income of the wealthiest individuals has skyrocketed, ${ }^{2}$ and the Great Recession and anemic recovery have only exacerbated these trends. ${ }^{3}$ Meanwhile, the rate of union membership among U.S. workers is lower than at any time since the New Deal, ${ }^{4}$ having dropped to $6.6 \%$ for private-sector workers. ${ }^{5}$ The adverse relationship between union membership rates and income inequality is unsurprising: collective bargaining has always been and remains one of the most effective tools that workers have to raise their standard of living. ${ }^{6}$

At the same time, the statute designed to protect workers' right to organize and collectively bargain, the National Labor Relations Act ("NLRA" or "Act"), has largely failed to achieve its objectives. It has been called "ossified," "doomed legal dinosaur,"9 and "an elegant tombstone for a dying institution." 10

1. See Drew DeSilver, U.S. Income Inequality, on Rise for Decades, Is Now Highest Since 1928, PEw ReSEARCH CENTER (Dec. 5, 2013), http://www.pewresearch.org/fact-tank/2013/12/05/u -s-income-inequality-on-rise-for-decades-is-now-highest-since-1928.

2. See Lawrence Mishel \& Heidi Shierholz, A Decade of Flat Wages: The Key Barrier TO SHARED PRosPERITY AND A Rising MidDLE ClAss 1 (2013) ("The wage and benefit growth of the vast majority, including white-collar and blue-collar workers and those with and without a college degree, has stagnated, as the fruits of overall growth have accrued disproportionately to the richest households.").

3. See Emmanuel Saez, Striking it Richer: The Evolution of Top Incomes in the United States 4 (U.C. Berkeley, Working Paper, 2013), available at http://elsa.berkeley.edu/ saez/saez -UStopincomes-2012.pdf ("Top 1\% incomes grew by $31.4 \%$ while bottom $99 \%$ incomes grew only by $0.4 \%$ [from 2009 to 2012 ]. Hence, the top $1 \%$ captured $95 \%$ of the income gains in the first two years of the recovery.").

4. See Gerard Mayer, Union Membership Trends in the United States 22-23 app. A, tbl.A1 (2004); Steven Greenhouse, Share of the Work Force in a Union Falls to a 97-Year Low, $11.3 \%$, N.Y. TimES, Jan. 23, 2013, at B1.

5. Economic News Release, Bureau of Labor Statistics, Union Members - 2014 (Jan. 23, 2015), available at http://www.bls.gov/news.release/union2.pdf. Union membership is concentrated in a few key industries while union rates in industries with high numbers of low-wage workers approach zero. For instance, while $20 \%$ of transportation workers and $13 \%$ of construction workers are unionized, only $1.4 \%$ of agricultural workers and $1.2 \%$ of food service workers are represented by a union. Id. at tbl.3 (2013).

6. The causes of income inequality are complex and outside the scope of this paper. However, it is well-established that high union rates not only raise wages for unionized workers but also do the same for non-unionized workers in the same industry. See, e.g., LAWRENCE MisHEL \& Matthew Walters, How Unions Help All Workers 1 (2003) ("Unions raise wages of unionized by roughly $20 \%$ and raise compensation, including both wages and benefits, by about $28 \%$."). See also id. at 8 (noting that unions raise standards in non-union workplaces because of the "union threat effect").

7. 29 U.S.C. $\S \S 151-69$ (2012).

8. Cynthia L. Estlund, The Ossification of American Labor Law, 102 Colum. L. Rev. 1527, 1530 (2002).

9. Wilma B. Liebman, Decline and Disenchantment: Reflections on the Aging of the National Labor Relations Board, 28 BERKELEY J. EMP. \& LAB. L. 569, 570 (2007). 
The administrative agency tasked with enforcing the Act, the National Labor Relations Board ("NLRB" or "Board"), has lumbered for many decades under the weight of its own bureaucratic malaise, its hands tied by the text of the Act $^{11}$ and by the Supreme Court, which has whittled away at the rights of workers until only an unrecognizable nub remains. ${ }^{12}$ Emboldened by the lack of an effective enforcement regime, employers have increased their use of both legal and illegal anti-organizing tactics. ${ }^{13}$

These problems have led some workers, particularly low-wage and immigrant workers, to abandon the traditional collective bargaining model and the NLRB altogether. Worker centers and other non-traditional labor organizations have arisen in a space that exists outside of traditional labor law. ${ }^{14}$ These community-based organizations engage in advocacy, service provision, and organizing support for low-wage (often immigrant) workers. ${ }^{15}$ Their membership or constituency may be workers in a particular industry, ${ }^{16}$ ethnic

10. Paul C. Weiler, Promises to Keep: Securing Workers' Rights to Self-Organization Under the NLRA, 96 HARV. L. REV. 1769, 1769 (1983).

11. See infra Part II.A.

12. See, e.g., NLRB v. Mackay Radio \& Tel. Co., 304 U.S. 333, 345 (1938) (upholding right of employers to replace striking workers); Int'l Bhd. of Elec. Workers v. NLRB, 341 U.S. 694, 705 (1951) (upholding ban on secondary boycotts); Hoffman Plastic Compounds, Inc. v. NLRB, 535 U.S. 137 (2002) (prohibiting undocumented workers from recovering backpay). See also James Gray Pope, Labor and the Constitution: From Abolition to Deindustrialization, 65 TeX. L. REV. 1071, 1074 (1987) ("Over the past three decades, the Supreme Court has, in effect, relegated labor protest to a black hole ....”).

13. See Kate Bronfenbrenner, No Holds Barred: The Intensification of Employer OPPOSITION TO ORGANIZING 13 tbl.4 (2009) (noting an increase in the most common employer anti-organizing tactics from 1986 to 2003).

14. See, e.g., Saru Jayaraman \& Immanuel Ness, Models of Worker Organizing, in THE NEW IMMIGRANT WORKFORCE 71 (Sarumathi Jayaraman \& Immanuel Ness, eds. 2005); Victor Narro, Impacting Next Wave Organizing: Creative Campaign Strategies of the Los Angeles Worker Centers, 50 N.Y.L. Sch. L. Rev. 465, 467 (2006); Julie Yates Rivchin, Building Power Among Low-Wage Immigrant Workers: Some Legal Considerations for Organizing Structures and Strategies, 28 N.Y.U. REV. L. \& Soc. Change 397, 405 (2004). Janice Fine has written extensively on worker centers and the future of the U.S. labor movement. See JANICE FInE, Worker CENTERS: Organizing Communities at the Edge of THE Dream (2006); Janice Fine, Worker Centers: Organizing Communities at the Edge of the Dream, 50 N.Y.L. ScH. L. REV. 417, 419 (2006). Fine discusses three waves of worker center formation. The first occurred in the late 1970s and early 1980 s in response to changes in manufacturing and the rise of the largely non-unionized service industry. The second took place in the 1990s in response to the migration of Latino immigrants in large numbers to the United States. The third occurred in the $2000 \mathrm{~s}$, as the worker center movement grew from a large-city phenomenon to one that included suburban and rural communities as well. See FINE, supra, at 11.

15. See Fine, supra note 14, at 419.

16. See, e.g., GARMENT WORKER CENTER, http://garmentworkercenter.org/about/ (last visited May 23, 2015) ("The Garment Worker Center (GWC) is a worker rights organization whose mission is to organize low-wage garment workers in Los Angeles in the fight for social and economic justice."); NEW YORK TAXI WORKERS AllianCE, http://www.nytwa.org/mission-and -history/ (last visited May 23, 2015) ("Founded in 1998, NYTWA is the 18,000-member strong union of NYC taxicab drivers."); DOMESTIC WORKERS UNITED, http://www.domesticworkersunited .org/index.php/en/about (last visited May 23, 2015) ("Domestic Workers United (DWU) is an 
group,${ }^{17}$ or neighborhood or geographic area. ${ }^{18}$ Importantly, worker centers are not "labor organizations" as defined by the NLRA and therefore neither enjoy the privileges nor face the restrictions that traditional labor unions do. ${ }^{19}$ Although precise numbers are not available, worker centers are growing in number. According to one study, there were fewer than five worker centers nationwide in 1992 and several hundred today. ${ }^{20}$

But employers have not been caught flat-footed. Instead, they have responded forcefully with comprehensive anti-organizing campaigns, the purpose of which is to impede the success and growth of the worker center movement. ${ }^{21}$ At the center of many of these campaigns is an old tactic repurposed to respond to a new threat: the abuse of litigation and the discovery

organization of Caribbean, Latina and African nannies, housekeepers, and elderly caregivers in New York, organizing for power, respect, fair labor standards and to help build a movement to end exploitation and oppression for all.").

17. See, e.g., CASA LATiNA, http://www.casa-latina.org/about-us/what-we-believe (describing its mission as "empower[ing] Latino immigrants through educational and economic opportunities") (last visited July 6, 2015); ChineSE Progressive Association, http://www.cpasf.org/mission (last visited May 23, 2015) ("[T] he Chinese Progressive Association educates, organizes and empowers the low income and working class immigrant Chinese community in San Francisco to build collective power with other oppressed communities to demand better living and working conditions and justice for all people.").

18. See, e.g., MiAMI WORKERS CENTER, http://www.miamiworkerscenter.org/en/about-2 /mission-and-vision (last visited May 23, 2015) ("The Miami Workers Center organizes and develops conscious leadership within Miami's working class communities for economic, gender and racial equality."); NEW ORLEANS WORKERS' CENTER FOR RACIAL JUSTICE, http://www.nowcrj.org/about-2 (last visited July 6, 2015) (naming its constituency as "poor and working class communities of color in the Gulf Coast"). See also FINE, supra note 14, at 13 ("Most centers focus their work geographically, operating in a particular metropolitan area, city, or neighborhood.").

19. For an analysis of the status of worker centers under the NLRA, see Eli NadurisWeissman, The Worker Center Movement and Traditional Labor Law: A Contextual Analysis, 30 BERKELEY J. EMP. \& LAB. L. 232 (2009).

20. See Fine, supra note 14 , at 421 . Worker centers have not yet replicated the broad membership of traditional labor unions. Outside a few cities, such as New York and Los Angeles, their influence is still relatively limited. Only a tiny fraction of low-wage workers nationwide have the support of a worker center-there are 3.6 million workers making a wage at or below the minimum wage, see DeP'T OF LABOR, Bureau of LABOR STATISTICS, Characteristics of MinimuM WAGE WORKERS: 2012 (Feb. 26, 2013), available at http://www.bls.gov/cps /minwage2012.htm, while members of worker centers number in the thousands, see FINE, supra note 14, at 209 (stating that sixty-eight percent of worker centers have five hundred or fewer members).

21. For one such campaign, see WORKER CENTER WATCH, http://www.workercenterwatch .com (last visited May 23, 2015). Although Worker Center Watch refuses to reveal its donors, it is largely considered to be a front for big business. Kevin Bogardus, Industry Groups Vow to Expose Union-Backed Worker Centers, HILL, http://thehill.com/business-a-lobbying/322893-industry -groups-vow-to-expose-union-backed-worker-centers- (last visited Feb. 28, 2015). Likewise, the U.S. Chamber of Commerce has been very vocal in its opposition to worker centers. See, e.g., U.S. Chamber of Commerce Workplace Freedom Initiative, The New Model of Representation: AN OVERVIEW OF LEADING WORKER CENTERS (2014), available at http://www.workforcefreedom .com/sites/default/files/WFI\%20Worker\%20Center\%20Study\%20-\%20New\%20Model\%20of \%20Representation.\%20Final\%20version\%20downloaded\%202.20.14.pdf (arguing that worker centers represent a troubling development in labor law). 
process. These litigation tactics can take the form of a frivolous lawsuit (also known as a "strategic lawsuit against public participation" or "SLAPP"). ${ }^{22}$ Or they can take the form of a discovery request or deposition question within litigation brought by workers under federal employment laws. ${ }^{23}$ In both cases, the goal is the same: to prevent workers from organizing and bargaining collectively.

When most labor disputes were mediated by the NLRB, workers were protected from these tactics by evidentiary privileges developed by the Board. The Board protects workers' confidential communications concerning organizing and collective bargaining, ${ }^{24}$ as well as union membership lists from disclosure in Board proceedings. ${ }^{25}$ But labor disputes in both the union and nonunion context are now far more likely to end up in federal and state courts, where no such privileges exist and where the avenues for relief available to workers are limited and ineffective. The shift in litigation from administrative proceedings to state and federal forums has created a gap in protection of workers' labor rights that employers have exploited with increasing frequency. ${ }^{26}$

Rather than looking for ways to protect workers within the existing legal framework, this article looks elsewhere. Specifically, it looks to the power of

22. See generally George W. Pring \& Penelope Canan, SLAPPs: Getting Sued for SPEAKING OUT (1996).

23. See, e.g., Century Rest. \& Buffet, Inc., 358 N.L.R.B. No. 23, 2012 WL 1026129, at *16 (Mar. 27, 2012) (involving a factual situation in which the employer's attorney interrogated a worker during deposition regarding her membership in a union and conversations with union representatives). (1988).

24. Berbiglia, Inc., 233 N.L.R.B. 1476, 1495 (1977); Champ Corp., 291 N.L.R.B. 803, 818

25. Nat'1 Tele. Directory Corp., 319 N.L.R.B. 420, 421 (1995).

26. See Nat'l Emp't Law Project, Engaging in Direct Action Campaigns Without GETTING SLAPP'D, XXIII (2007) (“[E]mployers and their allies are becoming increasingly brazen in filing 'Strategic Lawsuits Against Public Participation,' or SLAPP suits, against workers' centers and other groups who have done nothing more than to speak up about wage and hour abuses."). For some examples of SLAPPs brought in the context of labor disputes, see Fashion 21 v. Coal. for Humane Immigrant Rights of L.A., 12 Cal. Rptr. 3d 493, 496 (Ct. App. 2004) (worker rights group sued by retailer for defamation); Smithfield Foods, Inc. v. United Food \& Commercial Workers Int'1 Union, 633 F. Supp. 2d 214 (E.D. Va. 2008) (suit filed against union for "smear campaign"); Monterey Plaza Hotel v. Hotel Employees \& Restaurant Employees Local 483, 82 Cal. Rptr. 2d 10 (1999) (defamation suit against union for comments related to retaliatory firing); NLRB Advice Memorandum, Beverly Enterprises-Pennsylvania, Case 6-CA-28130-(1-3) (medical services provider sued nurses for defamation because of flyers distributed as part of organizing campaign); B\&B Hospitality Group, LLC v. ROC-NY, Case No. 115230/2010 (N.Y. Sup. Ct.) (worker center sued for defamation by restaurant target in wage/hour campaign); Park v. Korean Immigrant Workers Advocates of S. Cal., B154294, 2002 WL 938274 (Cal. Ct. App. May 9, 2002) (restaurant owner sued worker center for defamation); Street Beat Sportswear, Inc. v. Nat'1 Mobilization Against Sweatshops, 698 N.Y.S.2d 820 (N.Y. Sup. Ct. 1999) (worker center and organizers sued by garment manufacturer for defamation); Redeye Grill, L.P. v. Rest. Opportunities Ctr. of New York, Inc., 824 N.Y.S.2d 758 (N.Y. Sup. Ct. 2006) (worker group sued for deceptive trade practices by restaurant); Magic Laundry Servs., Inc. v. Workers United Serv. Employees Int'l Union, No. CV-12-9654-MWF AJWX, 2013 WL 1409530 (C.D. Cal. Apr. 8, 2013). 
federal courts and state courts and legislatures to create an evidentiary privilege that would protect workers' confidential communications from disclosure in federal and state court proceedings. As proposed in this article, a labor organizing privilege would be held by the worker and would protect communications concerning organizing or collective bargaining between two or more workers, or between workers and their representatives.

It would be broader than the "union representative" privilege that has been recognized by a few courts and one state legislature, ${ }^{27}$ and advanced by some scholars. ${ }^{28}$ While it would protect union members, the organizing privilege could be extended to workers and organizers in the non-union context as well. ${ }^{29}$ It could also cover workers who are not technically "employees" under the relevant labor and employment statutes. ${ }^{30}$ By eliminating the gap that has arisen in the legal protection of workers' labor rights, a labor organizing privilege would change the balance of power ever so slightly in favor of workers, remedy the worst abuses by employers, and allow the worker center movement to flourish. Ultimately, protections such as a labor organizing privilege could serve to slow or even reverse the trends in income inequality that have plagued the United States over the past several decades.

This article will first examine the phenomenon of abusive litigation tactics, including why they have become so prevalent in labor disputes. ${ }^{31}$ It will then analyze the current remedies available to workers in these situations and show their insufficiency. ${ }^{32}$ Finally, this article will argue for the establishment of a labor organizing privilege derived from Section 7 of the NLRA and the First and Thirteenth Amendments of the U.S. Constitution. ${ }^{33}$

27. See infra notes $260-61$.

28. See, e.g., Michael D. Moberly, Extending a Qualified Evidentiary Privilege to Confidential Communications Between Employees and Their Union Representatives, 5 NEV. L.J. 508 (2005); Mitchell H. Rubinstein, Is a Full Labor Relations Evidentiary Privilege Developing?, 29 Berkeley J. EMP. \& LAB. L. 221 (2008); Leeann R. Gruwell Anderson, Turning the Key: Ensuring Evidentiary Privilege as Labor Counsel, 45 DrAKE L. REV. 491 (1997).

29. Although the NLRA protects non-union members' right to organize and collectively bargain, see Glomac Plastics, Inc., 234 N.L.R.B. 1309, 1311 (1978), the Act has been interpreted by the NLRB not to afford non-union members the same rights with respect to representation, at least in disciplinary proceedings, see In re IBM Corp., 341 N.L.R.B. 1288, 1288 (2004).

30. For example, many workers are excluded from the definition of "employee" under the NLRA. See 29 U.S.C. § 152(3) (2012) ("[T]he term 'employee' . . . shall not include any individual employed as an agricultural laborer, or in the domestic service of any family or person at his home, or any individual employed by his parent or spouse, or any individual having the status of an independent contractor....").

31. See infra Part I.

32. See infra Part II.

33. See infra Part III. 
I.

\section{ABUSIVE LITIGATION TACTICS}

What makes a litigation tactic abusive? The term is used in this article to describe a category of litigation tactics the purpose of which is not to prevail in the litigation but to further some other improper purpose. In this case, that improper purpose is to infringe on workers' right to organize and collectively bargain. ${ }^{34}$ More specifically, their purpose might be to inflict litigation costs, to chill organizing by seeking the names of union supporters, or to gain advantage by discovering workers' organizing strategy. ${ }^{35}$

Consider the case of Jimenez v. Vanderbilt Landscaping, L.L.C. Temporary guest workers, organized by the New Orleans Workers' Center for Racial Justice, filed suit against several labor contractors for labor trafficking and involuntary servitude, violations of the Fair Labor Standards Act ("FLSA"), the Tennessee Whistleblower Act, and federal civil rights statutes, and state common law claims. ${ }^{36}$ The workers alleged that their passports had been confiscated, that they had been forced to work against their will, ${ }^{37}$ and that their employer had kept them under surveillance and not allowed them to leave the property. ${ }^{38}$ When they complained, the employer conducted a forced private deportation of one of the worker leaders and threatened the other workers with deportation as well. ${ }^{39}$ After escaping, they sought help from the worker center.

In response to the lawsuit, the employer, Vanderbilt Landscaping, filed counterclaims against the workers for defamation/libel, invasion of privacy, tortious interference with business relations, intentional infliction of emotional distress, abuse of process, and civil conspiracy. ${ }^{40}$ The workers filed a motion to dismiss under the Tennessee Anti-SLAPP Act. ${ }^{41}$ The court dismissed some, but not all, of the claims, finding that the Anti-SLAPP Act only applied to statements made to governmental bodies. ${ }^{42}$ Buoyed by their successful opposition to the motion to dismiss, Vanderbilt then filed a motion to amend its

34. The term "abusive" may seem to imply a moral judgment against those who utilize them, but the term is intended to be descriptive, not normative. To the extent that calling something "improper" implies a moral judgment, that judgment exists in the NLRA itself, which establishes these rights and prohibits employers from infringing upon them.

35. Many of these purposes mirror Rule 11 of the Federal Rules of Civil Procedure, which provides for sanctions if a filing is "being presented for any improper purpose, such as to harass, cause unnecessary delay, or needlessly increase the cost of litigation." Fed. R. Civ. P. 11.

36. Complaint, Jimenez v. Vanderbilt Landscaping, LLC, No. 3:11-cv-00276 (M.D. Tenn. Mar. 24, 2011).

37. Id. 93.

38. Id. 44.

39. Id. $ๆ 7$.

40. Answer \& Counterclaims, Jimenez v. Vanderbilt Landscaping, LLC, No. 3:11-cv-00276 (M.D. Tenn. Apr. 20, 2011).

41. See TenN. Code AnN. § 4-21-1001 to -1004 (2015).

42. Jimenez v. Vanderbilt Landscaping, LLC, No. 3:11-cv-00276, 2011 WL 3027190, at*12 (M.D. Tenn. July 25, 2011). 
counterclaims to add the worker center and one of its organizers as counterdefendants, ${ }^{43}$ a move that threatened to create a conflict with the workers' legal counsel, an attorney employed by the worker center. ${ }^{44}$ The court denied the motion to amend, ${ }^{45}$ but the counterclaims against the workers continued through discovery. The case was ultimately settled, but not before Vanderbilt Landscaping attempted to reveal the workers' organizing strategy at depositions. ${ }^{46}$ In this case, as in many others, litigation became just one weapon in the employer's arsenal designed to prevent the workers from organizing and asserting their rights.

Employers' use of litigation and the discovery process to prevent the exercise of workers' labor rights is not new. In the early twentieth century, lawsuits seeking to enjoin union activity were common. ${ }^{47}$ Many of these injunctions were granted on the grounds that union activity amounted to an antitrust violation under the Sherman Act, which the Supreme Court had held applied to unions in $1908 .{ }^{48}$ Lawsuits of this type decreased after the passage of the Norris-LaGuardia Act of 1932, which prohibited courts from issuing injunctions in non-violent labor disputes, ${ }^{49}$ and remained relatively low through the 1950s and 1960s, when union power was at its zenith. ${ }^{50}$

Recently, however, there has been a resurgence of abusive litigation tactics. ${ }^{51}$ This has occurred for several reasons. First, there has been a welldocumented overall increase in illegal anti-organizing tactics by employers. ${ }^{52}$

43. Memo. in Supp. Counter-Plaintiffs' Mot. to Amend Counterclaims, Jimenez v. Vanderbilt Landscaping, LLC, No. 3:11-cv-00276 (M.D. Tenn. Aug. 22, 2011).

44. Jimenez v. Vanderbilt Landscaping, LLC, No. 3:11-cv-00276, 2012 WL 589462, at *3 (M.D. Tenn. Feb. 22, 2012), report and recommendation adopted, 2012 WL 1079149 (M.D. Tenn. Mar. 29, 2012).

45. Jimenez v. Vanderbilt Landscaping, LLC, No. 3:11-cv-00276, 2012 WL 1079149 (M.D. Tenn. Mar. 29, 2012).

46. The U.S. Department of Labor also investigated and fined Vanderbilt Landscaping $\$ 18,000$ in civil penalties for violations of the federal H-2B temporary nonimmigrant worker program. See Press Release, U.S. Dep’t of Labor, Vanderbilt Landscaping Pays \$18,000 Fine Following US Department of Labor Investigations into Violations of H-2B Temporary Nonimmigrant Worker Program (June 27, 2011), available at http://www.dol.gov/opa/media/press /whd/whd20110929.htm.

47. See William Forbath, Law and the Shaping of the American Labor Movement 6162 (1991) (reporting that an estimated forty-three hundred injunctions were issued in labor conflicts between 1880 and 1930).

48. Loewe v. Lawlor, 208 U.S. 274 (1908).

49. 29 U.S.C. $\S \S 101-15(2012)$.

50. For a discussion on how the Norris-LaGuardia Act affected the prevalence of employer lawsuits, see Ralph K. Winter Jr., Labor Injunctions and Judge-Made Labor Law: The Contemporary Role of Norris-LaGuardia, 70 YALE L.J. 70, 74-75 (1960).

51. See Paul More, Protections Against Retaliatory Employer Lawsuits After BE\&K Construction v. NLRB, 25 BERKELEY J. EMP. \& LAB. L. 205, 215 (2004).

52. See Bronfenbrenner, supra note 13, at 13 (noting that the number of tactics used by employers doubled between 1986 and 2003); Weiler, supra note 10, at 1769-80 (noting that the number of employees entitled to reinstatement after retaliatory discharges increased one thousand percent between 1957 and 1980). 
De-unionization has left workers vulnerable to all types of employer abuse, but particularly to abusive litigation tactics due to the high associated costs. Few worker centers, let alone unrepresented workers, have the resources to mount an aggressive legal defense if an employer files a retaliatory lawsuit. The resource asymmetry between employers and non-traditional labor organizations encourages employers to utilize abusive litigation tactics.

Second, both unions and worker centers have turned to organizing tactics that are more likely to draw SLAPPs. Unions traditionally relied upon Boardsupervised elections and collective bargaining to attain organizing goals. ${ }^{53}$ Today, as unions attempt to organize in industries without a strong union presence, such as the fast food industry, ${ }^{54}$ campaigns often include public components such as hand billing, rallies outside the employer's premises, and press conferences, which are more likely than negotiations behind closed doors to prompt claims of defamation and other state common law torts. ${ }^{55}$ Like unions, worker centers also rely heavily on public pressure to bring employers to the bargaining table, particularly because employers have no legal obligation to bargain with them in good faith. ${ }^{56}$ And worker centers rely on tactics, such as mass picketing and secondary boycotts that the NLRA prohibits unions from utilizing, ${ }^{57}$ which may be more likely to draw retaliatory lawsuits by employers. ${ }^{58}$

53. More, supra note 51, at 210-11.

54. Arun Gupta, The Story Behind America's Fast Food Worker Uprising, GuARDIAN (Nov. 11, 2013), http://www.theguardian.com/commentisfree/2013/nov/11/fast-food-workers-strike-end -game.

55. More, supra note 51, at 214 ("[U]nions increasingly incorporate a range of publicity and information-based tactics into their campaigns. Information-based tactics are not limited to the traditional picket line. Well-designed campaigns rely on research to identify and target the key decision-makers within the employer's broader corporate network, followed by extensive use of the media, handbilling, and public demonstrations."); Estlund, supra note 8, at 1605 ("As the law becomes increasingly ineffectual in combating employer illegality, and as the strike becomes increasingly suicidal for many employees in view of the lawful threat of permanent replacement, workers are turning to alternative forms of economic pressure to secure and enforce collective bargaining agreements as well as to gain recognition or the right to organize without employer opposition. These tactics target not only the 'primary' employer, who may often be relatively insulated from public pressure, but others who have ties to and leverage over the primary employer."). See also Jennifer Hill, Can Unions Use Worker Center Strategies?: In an Age of Doing More with Less, Unions Should Consider Thinking Locally but Acting Globally, 5 FIU L. REV. 551, 557 (2010) (arguing that unions must employ worker center strategies to combat antiorganizing tactics by employers).

56. For a more in-depth look at a worker center-led public campaign, see JENNIFER GORDON, Suburban Sweatshops 87 (2005). See also Working For Justice: The L.A. Model of ORGANIZING ADVOCACY (Ruth Milkman, Joshua Bloom \& Victor Narro eds., 2010), which details several worker-center led campaigns in Los Angeles.

57. Labor Management Relations (Taft-Hartley) Act § 301(a), 29 U.S.C. § 158(b) (2012).

58. For this reason, employers and their advocates have begun to argue that worker centers should be considered "labor organizations" under the NLRA and thus subject to the bans on secondary boycotts and mass picketing. See Stefan J. Marculewicz \& Jennifer Thomas, Labor Organizations by Another Name: The Worker Center Movement and its Evolution into Coverage under the NLRA and LMRDA, 13 Engage: J. FedERAlist SOC'y PRAC. GRPS. 79, 90 (2012). The 
Finally, several trends have converged to make federal litigation brought by workers more common. As Benjamin Sachs has noted, workers and worker centers are increasingly avoiding the NLRB altogether, instead turning to employment litigation in federal court to raise workplace standards. ${ }^{59}$ Unions, too, have begun anchoring organizing campaigns around wage-and-hour lawsuits. ${ }^{60}$ The number of FLSA lawsuits has risen steadily over the past twenty years, from roughly fourteen hundred in 1993 to over seven thousand in $2012 .^{61}$ Although wage-and-hour suits can only enforce minimum standards, and therefore cannot completely take the place of collective bargaining, such suits can serve as an important part of a larger organizing campaign. Indeed, in many low-wage industries, violations of wage-and-hour laws are so rampant that almost every labor dispute involves illegal employer practices that could be the subject of a federal lawsuit. ${ }^{62}$ A 2009 report, for example, found that two-thirds of low-wage workers in American cities had experienced a pay-related violation in the previous week. ${ }^{63}$ Seventy-six percent of low-wage workers who worked overtime were not paid the correct overtime rate, and twenty-six percent were paid less than the minimum wage. ${ }^{64}$ In certain industries, the violation rate was even higher. ${ }^{65}$ And enforcement of workplace laws by public agencies, such as the Department of Labor, has simultaneously diminished, further increasing the need and the demand for private litigation. ${ }^{66}$

NLRB has thus far rejected these arguments. See NLRB Advice Memorandum: Restaurant Opportunity Center (Redeye Grill), Case No. 02-CP-1067, at *2 (Nov. 30, 2006) (finding that the Restaurant Opportunity Center, a worker center in New York, was not a "labor organization" under Section 2(5) of the NLRA despite negotiating a settlement agreement with an employer because there was no evidence of a "pattern or practice" of such dealings); Ctr. for United Labor Action, 219 N.L.R.B. 873 (1975) (holding that the Center for United Labor Action, which led public campaigns in support of workers, was not a labor organization under the NLRA because it did not exist to deal with employers on behalf of employees).

59. Benjamin I. Sachs, Employment Law As Labor Law, 29 CARdozo L. Rev. 2685, 2687 (2008).

60. Catherine Ruckelshaus, Labor's Wage War, 35 Fordham UrB. L.J. 373, 400-01 (2008) (detailing examples of union-led efforts to enforce wage-and-hour laws).

61. William B. Gould IV, A PRimer on AMERicAN LABOr LAW 33 (2013).

62. See Naduris-Weissman, supra note 19, at 239 ("The worker centers' focus on statutory employment standards also reflects the fact that they often aim to serve workers with the least stable employment and lowest wages, in order to ensure minimum compliance with the law.").

63. Annette Bernhardt, Ruth Milkman, Nik Theodore, Douglas Heckathorn, Mirabai Auer, James DeFilippis, Ana luz González, Victor Narro, Jason Perelshteyn, Diana Polson \& Michael Spiller, Broken laws, Unprotected Workers: Violations of EMPLOYMENT AND LABOR LAWS IN AMERICA'S CiTIES 5 (2009).

64. Id. at 2 .

65. Id. at 30-31 (reporting that sixty-six percent of childcare workers, more than forty percent of workers in apparel and textile manufacturing, and fifty percent of dry cleaning workers make less than the minimum wage).

66. Annette Bernhardt \& Siobhán McGrath, Trends in Wage and Hour Enforcement BY THE U.S. DEPARTMENT OF LABOR, 1975-2004, at 2 (2005) (finding that, from 1975 to 2004, enforcement actions by the U.S. Department of Labor declined thirty-six percent as the number of workers covered by applicable laws rose by fifty-five percent). 
Once workers have filed a lawsuit, an employer may turn to abusive litigation tactics for no other reason than that it provides the best defense to claims that otherwise would be very difficult for the employer to win. This abuse of the legal system wastes judicial resources, discourages workers from bringing forth meritorious claims, and, ultimately, creates an environment of fear that allows unethical employers to continue to abuse workers with impunity.

II.

\section{CURRENT REMEDIES}

A worker targeted by an abusive litigation tactic currently has two options. First, the worker can follow the traditional route and file an unfair labor practice charge with the NLRB. Second, in some states, the worker can file a motion to dismiss under an anti-SLAPP statute. Both of these remedies suffer from limitations that render them ineffective for addressing the problem of abusive litigation tactics.

\section{A. NLRB Unfair Labor Practice Charge}

Workers who fall within the definition of "employee" under the NLRA, ${ }^{67}$ regardless of whether they are unionized or not, ${ }^{68}$ enjoy the rights established in section 7 of the Act. Section 7 includes the right to engage in "concerted activities for the purpose of collective bargaining or other mutual aid or protection." 69 In theory, employers who use abusive litigation tactics against their workers should be subject to an unfair labor practice charge with the NLRB, which could then move to enjoin the lawsuit or discovery. ${ }^{70}$ Indeed, in the early decades after the passage of the NLRA, the NLRB occasionally did just that. ${ }^{71}$

Unfortunately, in 1983 the Supreme Court, in Bill Johnson's Restaurants Inc. v. $N L R B$, severely limited this remedy. ${ }^{72}$ Citing the right to petition and First Amendment values, the Court held that " $[t]$ he filing and prosecution of a wellfounded lawsuit may not be enjoined as an unfair labor practice, even if it would not have been commenced but for the plaintiff's desire to retaliate against the defendant for exercising rights protected by the Act." $" 73$ This decision essentially ratified a form of intentional retaliation by employers. An employer's right to petition now trumps a worker's right to organize and collectively bargain free from retaliation.

67. 29 U.S.C. $\S 152(3)(2012)$.

68. Glomac Plastics, Inc., 234 N.L.R.B. 1309, 1311 (1978).

69. 29 U.S.C. $\S 157$ (2012).

70. $I d . \S 160(\mathrm{j})(2012)$.

71. See, e.g., Power Sys., Inc., 239 N.L.R.B. 445, 450 (1978); United Credit Bureau of Am., Inc., 242 N.L.R.B. 921,926 (1979).

72. 461 U.S. 731 (1983).

73. Id. at 743 . 
While the Supreme Court did permit the NLRB to enjoin "baseless" lawsuits, ${ }^{74}$ it did not explain how the NLRB should determine which suits were "well-founded" and which were "baseless" without allowing costly and damaging discovery. Perhaps most problematic, the Court held that the NLRB could not use credibility determinations to decide whether the employer's lawsuit was baseless. ${ }^{75}$ In other words, if an employer is savvy enough to make allegations that are not legally deficient and are plausible on their face, then Bill Johnson's Restaurants prevents the NLRB from seeking an injunction, even when the employer admits that the lawsuit is retaliatory. The purpose of these lawsuits is rarely to obtain a final judgment, but rather to infringe on the exercise of labor rights. The inability of the NLRB to issue timely injunctions makes this a recognized wrong without a meaningful remedy. ${ }^{76}$

Similarly, the NLRB has developed a three-part test to determine when discovery into workers' organizing activities is not an unfair labor practice: the discovery must be relevant, it must not have an illegal objective, and the employer's interest in obtaining the information must outweigh the employees' confidentiality interests under Section 7 of the Act. ${ }^{77}$ Unfortunately, this test suffers from many of the same problems of proof as the test in Bill Johnson's Restaurants. While the Board has not articulated which employer interests would justify discovery into employees' collective bargaining and organizing activity, many of the claims commonly present in SLAPPs would conceivably give employers ample justification to probe into workers' communications. By the time such claims are found to be baseless, the damage is already done.

Putting aside the practical problems in applying these legal standards, the process itself also serves as an impediment to an effective remedy. Because the NLRA lacks a private right of action, a worker must file an unfair labor practice charge with the Board, and the General Counsel (the investigatory and prosecutorial arm of the NLRB) then decides whether to issue a complaint. ${ }^{78}$ If

74. Id. at 744 ("[I]t is an enjoinable unfair labor practice to prosecute a baseless lawsuit with the intent of retaliating against an employee for the exercise of rights protected by $\S 7$ of the NLRA.").

75. Id. at 745 .

76. The Supreme Court rejected the argument that the NLRA preempts state libel and defamation laws in Linn v. United Plant Guard Workers, Local 114, allowing suits to proceed when an employer can show "actual malice" and actual harm. 383 U.S. 53, 64-65 (1966). See also Kati L. Griffith, The NLRA Defamation Defense: Doomed Dinosaur or Diamond in the Rough?, 59 AM. U. L. REV. 1, 10 (2009) (discussing NLRA defamation defense). The Supreme Court has issued similar decisions denying preemption for two other state law claims commonly brought in retaliatory lawsuits: trespass, see Sears, Roebuck \& Co. v. San Diego Cnty. Dist. Council of Carpenters, 436 U.S. 180 (1978), and emotional distress, see Farmer v. United Brotherhood of Carpenters, 430 U.S. 290 (1977).

77. Guess?, 339 N.L.R.B. 432, 434 (2003). See also Century Rest. \& Buffet, Inc., 358 N.L.R.B. No. 23, 28 (Mar. 27, 2012). The NLRB has also held that it can be an unfair labor practice for an employer to seek union membership lists during the course of collateral court proceedings. See Wright Elec., Inc., 327 N.L.R.B. 1194, 1195 (1999).

78. See Gould, supra note 61, at 39, 77. 
the General Counsel declines to issue a complaint, there is no appeal. ${ }^{79}$ This system places workers at the mercy of the NLRB, which, because of resources and politics, issues few complaints. ${ }^{80}$ As the Supreme Court's recent decision in NLRB v. Noel Canning shows, dedicated political opposition to the NLRB can effectively neuter its ability to do much of anything. ${ }^{81}$

Even when a complaint is issued, the sheer bureaucratic inefficiency of the NLRB makes the remedy illusory. The average time from the filing of a charge to Board decision was 483 days in 2009 , the last year the NLRB made such information available. ${ }^{82}$ The median number of days a case had been pending was 963 days. ${ }^{83}$ This provides plenty of time for the employer to use the information produced in discovery to fire a worker leader, break up an organizing campaign, or intimidate a worker into dropping a lawsuit or settling a frivolous SLAPP. Although the NLRB can move for a preliminary injunction in federal district court once a complaint has been issued, ${ }^{84}$ the average time from the filing of a charge to the issuance of the complaint was still one hundred days in $2009 .{ }^{85}$ Particularly when discovery takes the form of a deposition, where questions must be answered in real time, this "remedy" is nothing of the sort. ${ }^{86}$

If the NLRB could effectively deter abusive litigation tactics by employers, then the lack of timely injunctions would be less problematic. But the paltry remedies available under the NLRA severely limit its deterrent effect. ${ }^{87}$ The

79. 29 U.S.C. $§ 153$ (d) (2012) ("[The General Counsel] shall have final authority, on behalf of the Board, in respect of the investigation of charges and issuance of complaints under section 160 of this title."); NLRB v. United Food and Commercial Workers Union Local 23, 484 U.S. 112, 122-23 (1987) (finding there was no judicial review of General Counsel's prosecutorial discretion); Vaca v. Sipes, 386 U.S. 171, 182 (1967) ("[T]he Board's General Counsel has unreviewable discretion to refuse to institute an unfair labor practice complaint."). See also GouLD, supra note 61, at 98-99 ("[T]he General Counsel has plenary authority to determine whether an unfair labor practice should be issued . . . even arbitrary conduct cannot be reversed by the courts.").

80. In 1993, the Board issued 3576 complaints out of 33,744 unfair labor practice charges filed, or in $10.6 \%$ of cases. 58 NLRB ANN. REP. 6, 9 (1993). In 2009, the last year such information was publicly available, that number had dropped to 5.1\%. 74 NLRB ANN. REP. 7 (2009).

81. 134 S. Ct. 2550 (2014) (striking down President's power to recess appoint members of the NLRB); Richard Lempert, Noel Canning, Polarization, and Institutional Gridlock, BrooKINGS (July 1, 2014), available at http://www.brookings.edu/blogs/fixgov/posts/2014/07/01-noel-canning -presidential-appointments-lempert.

82. 74 NLRB ANN. REP. 152 (2009).

83. Id.

84. 29 U.S.C. § 160(j) (2012); Frankl v. HTH Corp., 650 F.3d 1334, 1340-41 (9th Cir. 2011).

85. 74 NLRB ANN. REP. 152 (2009).

86. The Board seeks a preliminary injunction pursuant to 29 U.S.C. $\S 160(j)$ in only a small percentage of unfair labor practice cases. In 2009, the Board sought injunctions in only 23 cases. 74 NLRB ANN. REP. 16 (2009).

87. In fact, the Supreme Court has held that the NLRB does not have the power to construct remedies the purpose of which is to deter. See Local 60, United Brotherhood of Carpenters \& Joiners v. NLRB, 365 U.S. 651, 659 (1961) (Harlan, J., concurring) ("Deterrence is certainly a 
Board cannot award punitive damages. ${ }^{88}$ The centerpiece of the NLRA's remedial regime is compensatory damages in the form of back pay, but unfair labor practices committed during the course of litigation often do not result in an award of back pay. ${ }^{89}$ Moreover, after Hoffman Plastic Compounds, Inc. $v$. National Labor Relations Board, the Board cannot award back pay at all to undocumented workers. ${ }^{90}$ This excludes an estimated eight million working undocumented immigrants, ${ }^{91}$ amounting to $5.2 \%$ of the U.S. workforce, ${ }^{92}$ from this important remedy. In many cases the Board's remedies are limited to weak forms of relief such as requiring the employer to post a notice informing workers of their rights under the NLRA. ${ }^{93}$

The Board can theoretically order the employer to pay litigation expenses, including attorney's fees and costs, incurred as a result of an employer's unfair labor practice. ${ }^{94}$ But in BE\&K Construction v. National Labor Relations Board, the Supreme Court limited the Board's ability to do so. ${ }^{95}$ Reasoning from its decision in Bill Johnson's Restaurants, the Court held that retaliatory lawsuits that are reasonably based, but ultimately unsuccessful, do not constitute an unfair labor practice. In $B E \& K$, the NLRB had found that the employer's lawsuit had an "utter absence of merit." 96 All of the claims had been dismissed on summary judgment. ${ }^{97}$ Yet, this did not meet the Court's definition of a baseless lawsuit. The NLRB subsequently held that a retaliatory lawsuit was an unfair labor practice only if it was "objectively baseless," meaning that "no reasonable litigant would have expected to succeed on the merits of the action." 98 Not surprisingly, the NLRB has held few lawsuits to be unfair labor practices since

desirable even though not in itself a sufficiently justifying effect of a Board order."). It is not surprising, then, that the NLRB's remedies have largely failed to have a deterrent effect.

88. See, e.g., Republic Steel Corp. v. NLRB, 311 U.S. 7, 11-12 (1940); Consol. Edison v. NLRB, 305 U.S. 197, 236 (1938); Ex-Cell-O Corp., 185 N.L.R.B. 107, 117 n.36 (1970).

89. Even when back pay is available, its deterrent effect is minimal. See, e.g., Weiler, supra note 10, at 1789-90; Michael H. Gottesman, In Despair, Starting Over: Imagining a Labor Law for Unorganized Workers, 69 CHI.-KENT L. REV. 59, 75 (1994) ("The current NLRA's limitation to back pay is an invitation to violations: unless employers are caught virtually one hundred percent of the time, there is economic incentive to violate."); Remedies for Employer Unfair Labor Practices During Union Organizing Campaigns, 77 YALE L.J. 1574, 1577 (1968) ("Existing remedies such as reinstatement with back pay for discriminatorily discharged workers have been justifiably called 'too little and too late' and "no more than a license fee for union busting." (citations omitted)).

90. 535 U.S. 137 (2002).

91. JeFFrey S. PASSEl \& D'Vera COHN, UnAuthorized ImMigrant POPUlation: NATIONAL AND STATE TRENDS 17 (2010), available at $\mathrm{http}$ //www.pewhispanic.org/files/reports/133.pdf.

92. Id.

93. See Hoffman Plastic Compounds, Inc. v. NLRB, 535 U.S. 137, 152 (2002) (employer must still post notice even if back pay is not available).

94. Bill Johnson's Restaurants, Inc. v. NLRB, 461 U.S. 731, 747 (1983).

95. 536 U.S. 516, 533-34 (2002).

96. Id. at 523 .

97. Id.

98. See BE \& K Constr. Co., 351 N.L.R.B. 451, 457 (2007). 
$B E \& K,{ }^{99}$ in part because the General Counsel has largely stopped filing complaints when retaliatory lawsuits are at issue. ${ }^{100}$

One possible way to fix this lack of meaningful remedies is to pursue labor law reforms that would increase the efficacy of the NLRA. Scholars have proposed, for instance, a legislative fix to Hoffman Plastic, an amendment that would allow the Board to award punitive or liquidated damages, ${ }^{101}$ or a new private right of action so that workers could pursue their unfair labor practice claims in federal court. ${ }^{102}$ Given that the NLRA has remained "virtually untouched" since $1959,{ }^{103}$ these reforms are unlikely to come to fruition. ${ }^{104}$ Yet even these pie-in-the-sky proposals would do nothing to protect the millions of workers - for instance, agricultural and domestic workers and the everexpanding category of "independent contractors"105 - who are explicitly excluded from the NLRA's protections and cannot bring a charge at all. ${ }^{106}$ For these workers in particular, it is important to find new ways of protecting workers from abusive litigation tactics by employers that do not depend on the NLRB.

\section{B. Anti-SLAPP Statutes}

The term "SLAPP" was first coined by Penelope Canan and George W. Pring in the 1980 s to identify a growing number of lawsuits designed to chill

99. But see Milum Textile Servs., 357 N.L.R.B. No. 169 (Dec. 30, 2011).

100. See Dilling Mech. Contractors, Inc., 357 N.L.R.B. No. 56 (Aug. 19, 2011) (General Counsel decided to withdraw unfair labor practice charge after $B E \& K$ ); Guideline Memorandum Concerning BE \& K Construction Co., 351 N.L.R.B. No. 29, 2007 WL 4623445 (Sept. 29, 2007) (detailing the myriad of steps investigators must take before charging an unfair labor practice for retaliatory lawsuits after $B E \& K$ ).

101. See, e.g., Gottesman, supra note 89 , at 75 .

102. See, e.g., James J. Brudney, Isolated and Politicized: The NLRB's Uncertain Future, 26 COMP. LAB. L. \& POL'y J. 221, 231-34 (2005); Estlund, supra note 8, at 1551-58; RicharD D. KAhlenberg \& Moshe Z. MARvit, Why Labor Organizing Should Be A Civil Right 4 (2012).

103. Estlund, supra note 8, at 1533.

104. Some reforms have gained traction in recent years. For instance, the recent comprehensive immigration reform bill that passed the Senate contained a legislative override of the Hoffman Plastic decision. See Border Security, Economic Security, and Immigration Modernization Act, S. 744, 113th Cong. § 3274a (2013). That bill died in the House and the prospect for similar legislation is uncertain at best.

105. An estimated ten percent of workers are misclassified as independent contractors. Annette Bernhardt, Heather Boushey, Laura Dresser \& Chris Tilly, An Introduction to the "Gloves-off Economy," in THE Gloves-OfF ECONOMY: WorkPlace STANDARDS AT THE BotTOM OF AMERICA's LABOR MARKET 1, 8 (Annette Bernhardt, Heather Boushey, Laura Dresser \& Chris Tilly eds., 2008). Although the data is incomplete, this number appears to be rising over time. Id. at 11. In addition, recent court decisions have narrowed the definition of employee in many labor and employment statutes. See Noah D. Zatz, Employment Law, in The Gloves-Off Economy: WorkPlace StANDARdS AT the BotTOM OF AMERICA's LABOR MARKeT, supra, at 34-35 (citing Nationwide Mutual Insurance Co. v. Darden, 503 U.S. 318 (1992)).

106. 29 U.S.C. $§ 152(3)$ (2012) (“The term 'employee' . . shall not include any individual employed as an agricultural laborer, or in the domestic service of any family or person at his home ... or any individual having the status of independent contractor ...."). 
speech on matters of public concern. ${ }^{107}$ According to Canan and Pring, the purpose of SLAPPs is not success on the merits, but rather "to intimidate and harass . . critics into silence." 108 They defined a SLAPP as (1) a civil complaint or counterclaim (for damages or injunctive relief); (2) filed against nongovernmental individual or groups; (3) because of their communications to a government body, official, or electorate; (4) on a matter of public concern. ${ }^{109}$ Common claims brought as part of SLAPPs include defamation, business torts, judicial-administrative torts (malicious prosecution/abuse of process), conspiracy, constitutional and civil rights violations, and miscellaneous wrongs (including nuisance, invasion of privacy, and attacks on nonprofit tax status). ${ }^{110}$ Early SLAPPs were brought largely in the context of land use and zoning disputes, ${ }^{111}$ though Pring and Canan identified SLAPPs in other areas, including in labor disputes. ${ }^{112}$

In response to the problem of SLAPPs, some states enacted anti-SLAPP laws designed to give the targets of SLAPPs tools with which to protect themselves. These laws vary by state, but in general they provide for early dismissal of claims brought to chill protected activity, either by establishing a heightened pleading standard, or by requiring SLAPP plaintiffs to come forward with evidence proving their claims are viable at the motion to dismiss stage. ${ }^{113}$ Most statutes also allow victorious SLAPP targets to recover attorney's fees and costs. $^{114}$ Twenty-eight states and one territory have enacted anti-SLAPP statutes, ${ }^{115}$ and three more states have extended common law anti-SLAPP

107. See Penelope Canan \& George W. Pring, Strategic Lawsuits Against Public Participation, 35 Soc. Problems 506 (1988); George W. Pring \& Penelope Canan, Slapps: GetTing Sued for SPeAKING Out 3 (1996). Pring and Canan's research comes, in part, from a study they completed on SLAPPs in 1984 as part of the Political Litigation Project at the University of Denver. $I d$. at 209.

108. Edmond Costantini \& Mary Paul Nash, SLAPP/Slappback: The Misuse of Libel Law for Political Purposes and a Countersuit Response, 7 J.L. \& PoL. 417, 423 (1991).

109. George W. Pring, SLAPPs: Strategic Lawsuits Against Public Participation, 7 PACE ENVTL. L. REV. 3, 8 (1989).

110. George W. Pring \& Penelope Canan, Strategic Lawsuits Against Public Participation ("SLAPPs"): An Introduction for Bench, Bar and Bystanders, 12 BRIDGEPORT L. Rev. 937, 947 (1992).

111. PRING \& CANAN, supra note 107, at 30 (finding real estate SLAPPs to be the single largest category, amounting to one third of cases); Paul D. Wilson, Of Sexy Phone Calls and WellAimed Golf Balls: Anti-SLAPP Statutes in Recent Land-Use Damages Litigation, 36 UrB. LAw. 375, 376 (2004) (calling land use SLAPPs the "paradigm case").

112. PRING \& CANAN, supra note 107, at 141.

113. Bruce E. H. Johnson \& Sarah K. Duran, A View from the First Amendment Trenches: Washington State's New Protections for Public Discourse and Democracy, 87 WASH. L. REV. 495 , 502-03 (2012).

114. $I d$. at 503

115. Id. at 503 n.48 (citing ARIZ. Rev. StAT. ANN. §§ 12-751 to -752 (Supp. 2011); ARK. Code AnN. $\S ~ 16-63-501$ to -508 (2005); Cal. Civ. Proc. Code $\S 425.16$ (West 2004); Del. Code ANN. tit. 10, $\S \S 8136-8138$ (1999); D.C. CodE $\S \S 16-5501$ to -5505 (Supp. 2011); Fla. STAT. ANN. § 720.304(4) (West 2010); Fla. STAT. ANN. § 768.295 (West 2011); GA. CodE ANN. § 9-1111.1 (2006); GA. CODE ANN. § 51-5-7(4) (2000); 7 GuAm CODE ANN. §§ 17101-17109 (2005); 
protections. ${ }^{116}$ Several other states have considered anti-SLAPP legislation in recent years. ${ }^{117}$ There is no federal anti-SLAPP statute, although there have been several recent attempts to pass one. ${ }^{118}$

As Pring and Canan recognized, employers can and do use SLAPPs to prevent or chill the exercise of workers' right to organize and collectively bargain. In addition to the more common SLAPP claims, employers also have resorted to bringing racketeering claims under the federal Racketeer Influenced and Corrupt Organizations Act ("RICO"). ${ }^{119}$ Anyone can utilize abusive litigation tactics, including workers and labor organizations. ${ }^{120}$ However, SLAPPs are most effective when filed against the vulnerable and underresourced, who are more likely to be workers and their representatives than employers. $^{121}$

Invoking anti-SLAPP statutes instead of filing an unfair labor practice charge has several advantages for workers seeking a remedy for abusive litigation tactics. The workers can bring the claims themselves rather than

Haw. Rev. Stat. AnN. $\S \S 634 \mathrm{~F}-1$ to -4 (LexisNexis 2007); 735 Ill. Comp. Stat. AnN. 110/15 to 125 (West 2011); Ind. Code AnN. $\S$ 34-7-7-1 to -10 (LexisNexis 2008); LA. Code Civ. Proc. AnN. art. 971 (2005); Me. Rev. Stat. Ann. tit. 14, § 556 (2003); Md. Code AnN., Cts. \& Jud. Proc. § 5-807 (LexisNexis 2006); MASS. ANN. LAWS ch. 231, § 59H (LexisNexis 2009); MinN. Stat. AnN. §§ 554.01-.05 (West 2010); Mo. Ann. Stat. § 537.528 (West 2008); Neb. Rev. Stat. ANN. $\S \S 25-21,241$ to $-21,246$ (LexisNexis 2004); NEV. REV. STAT. $\S \S 41.637, .650-.670$ (2012); N.M. STAT. ANN. § 38-2-9.1 (Supp. 2011); N.Y. Civ. Rights LaW §§ 70-a, 76-a (McKinney 2009); N.Y. C.P.L.R. 3211(g) (McKinney Supp. 2012); OKLA. Stat. AnN. tit. 12, § 1443.1 (West 2010); Or. Rev. Stat. AnN. $\S \S 31.150-.155$ (West Supp. 2011); 27 PA. Cons. Stat. AnN. $§ \S 7707$, 8301-8303 (West 2009); R.I. GEN. LaWs §§ 9-33-1 to -4 (1997); TENN. CODE ANN. §§ 4-21-1001 to -1004 (2011); TeX. Civ. Prac. \& Rem. Code AnN. §§ 27.001-.011 (West Supp. 2011); Utah Code AnN. §§ 78B-6-1401 to -1405 (West 2009 \& Supp. 2011); VT. STAT. AnN. tit. 12, § 1041 (2012); WASH. REV. CODE $\S \S 4.24 .510-.525$ (2010)).

116. Id. at 503 n. 48 (citing Protect Our Mountain Environment, Inc. v. District Court, 677 P.2d 1361 (Colo. 1984)); Royce v. Willowbrook Cemetery, Inc., No. XO8CV010185694, 2003 WL 431909 (Conn. Super. Ct. Feb. 3, 2003) (recognizing that a plaintiff's objectively baseless defamation suit could violate the Connecticut Unfair Trade Practices Act); Harris v. Adkins, 432 S.E.2d 549 (W. Va. 1993).

117. H.R. 5036, 95th Leg., Reg. Sess. (Mich. 2009); Citizen Participation Act, H.R. DRH30241-MH-45, 2011 Gen. Assemb. (N.C. 2011).

118. The Citizen Participation Act of 2009, H.R. 4364, 111th Cong. (2009) ("To protect $[\mathrm{F}]$ irst $[\mathrm{A}] \mathrm{mendment}$ rights of petition and free speech by preventing States and the United States from allowing meritless lawsuits arising from acts in furtherance of those rights, commonly called 'SLAPPs,' and for other purposes.'); The SPEAK FREE Act of 2015, H.R. 2304, 114th Cong. (2015).

119. More, supra note 51, at 218-19; James J. Brudney, Collateral Conflict: Employer Claims of Rico Extortion Against Union Comprehensive Campaigns, 83 S. CAL. L. REv. 731, 733 (2010).

120. See PRING \& CANAN, supra note 107 , at 141 .

121. Though now out-of-date, Pring and Canan's 1984 study showed that individuals and small organizations are much more likely to be targeted by SLAPPs than large corporations or other entrenched interests. Ninety percent of the SLAPPs in the study were filed against individuals, not corporations or organizations. Id. at 214. Eighty-seven percent of SLAPPs were filed against local individuals or groups, which are less likely to have the resources to effectively defend against them. Id. at 215 . 
depending on the NLRB to prosecute their claims. Anti-SLAPP statutes are designed to work quickly, allowing the dismissal of retaliatory claims before discovery has commenced. When invoked successfully, abusive lawsuits are dismissed in their entirety, preventing them from having their intended chilling effect. And the availability of attorney's fees to the prevailing party provides a strong incentive for employers to avoid filing SLAPPs in the first place.

However, anti-SLAPP statutes are not a panacea. For one thing, there is no protection at all for workers in the nineteen states without anti-SLAPP statutes or common law protections, and the applicability of existing state statutes in federal court is unclear. ${ }^{122}$ Moreover, many early anti-SLAPP statutes were enacted to address the specific concern of land use and zoning SLAPPs. ${ }^{123}$ Other antiSLAPP statutes similarly apply only to lawsuits concerning certain areas of public concern, such as environmental laws and regulations. ${ }^{124}$

A few states, such as Florida and California, have amended their antiSLAPP statutes to provide more comprehensive protections. ${ }^{125}$ But even in

122. Compare Henry v. Lake Charles Am. Press, LLC, 566 F.3d 164 (5th Cir. 2009) (applying Louisiana's anti-SLAPP statute), United States ex rel. Newsham v. Lockheed Missiles \& Space Co., 190 F.3d 963 (9th Cir. 1999) (holding that motion to strike and attorneys' fees provisions of California's anti-SLAPP statute applies in federal diversity suits), and Godin v. Schencks, 629 F.3d 79, 92 (1st Cir. 2010) (applying Maine's anti-SLAPP statute), with Abbas v. Foreign Policy Group, LLC, 783 F.3d 1328 (D.C. Cir. 2015) (holding that state anti-SLAPP statutes do not apply in diversity suits in federal court), Stuborn Ltd. v. Bernstein, 245 F. Supp. 2d 312, 316 (D. Mass. 2003) (declining to apply the Massachusetts anti-SLAPP statute), Thomas v. Fry's Elec., Inc., 400 F.3d 1206, 1206-07 (9th Cir. 2005) (declining to import heightened pleading standard in California's anti-SLAPP statute into federal forum), Adventure Outdoors, Inc. v. Bloomberg, 519 F. Supp. 2d 1258, 1278 (N.D. Ga. 2007) (declining to apply Georgia's antiSLAPP statute in federal suit), and Yeshiva Chofetz Chaim Radin, Inc. v. Vill. of New Hempstead, 98 F. Supp. 2d 347, 360 (S.D.N.Y. 2000) (holding that the New York anti-SLAPP statute does not apply in federal question cases).

123. For instance, New York's anti-SLAPP statute only applies to lawsuits brought by a "public applicant or permittee" and must be "materially related to any efforts of the defendant to report on, comment on, rule on, challenge or oppose such application or permission." N.Y. CIV. RIGHTS LAW § 76-a(a). See also Guerrero v. Carva, 779 N.Y.S.2d 12, 21 (N.Y. App. Div. 2004) (finding that anti-SLAPP statute did not apply to dispute between landlord and tenants because flyers at issue did not specifically identify an application or petition by landlord). Tennessee similarly restricts its anti-SLAPP statute to statements made directly to a governmental body. See TENN. CODE ANN. §§ 4-21-1001 to -1004 (2011); Jimenez v. Vanderbilt Landscaping, LLC, No. 311-0276, 2011 WL 3027190, at*2 (M.D. Tenn. July 25, 2011).

124. See, e.g., 27 PA. Cons. StAT. AnN. § 7707 (2000) (applying to environmental law and regulation).

125. Fla. Stat. AnN. § 768.295 (amended 2015); Cal. Civ. Proc. Code $§ 425.16$ (amended 1997). In Florida, the previous anti-SLAPP statute only applied to suits filed by government entities. See Citizen Participation in Government Act, 2000 Fla. Sess. Law Serv. Ch. 2000-174 (H.B. 135) (2000). The revised statute applies to suits filed by any plaintiff involving the "exercise [of] the constitutional right of free speech in connection with a public issue." FLA. STAT. ANN. $\S 768.295$ (2015). In California, the legislature amended the statute in 1997 in response to court decisions narrowly construing the meaning of "public interest" under the statute. See Act to Amend Section 425.16 of the Code of Civil Procedure, Relating to Civil Actions, 1997 Cal. Legis. Serv. Ch. 271 (S.B. 1296) (1997). Since this change, courts have held that the anti-SLAPP statute specifically applies in the labor dispute context. See, e.g., Monterey Plaza Hotel v. Hotel Emps. \& 
states with broad anti-SLAPP statutes, artful pleadings can often survive a motion to dismiss, leaving workers vulnerable to abusive discovery, even if they ultimately prevail in the suit. Moreover, some judges are reluctant to dismiss suits at an early stage, wary of inadvertently throwing out meritorious cases.

This reluctance is rooted in a deeper criticism of anti-SLAPP statutes - that they contribute to the problem they seek to solve by restricting the right to petition. The New Hampshire Supreme Court has held that an anti-SLAPP statute would be inconsistent with the state constitution for precisely this reason, ${ }^{126}$ and scholars have criticized California's broad anti-SLAPP statute for limiting litigants' access to courts, ${ }^{127}$ a criticism that Pring and Canan identified when first advocating for anti-SLAPP statutes in the 1980s. ${ }^{128}$ Other potential constitutional concerns lurk around the corner. For instance, the Washington Supreme Court recently invalidated that state's new anti-SLAPP law on the ground that requiring the judge, rather than a jury, to weigh the evidence at the prima facie stage violated the plaintiff's right to a jury trial. ${ }^{129}$ While the New Hampshire and Washington supreme courts are currently in a small minority, this concern for protecting employers' constitutional rights provides a good reason not to rely solely on anti-SLAPP statutes to protect workers' right to organize. $^{130}$

Finally, anti-SLAPP statutes are completely ineffective when employers engage in abusive discovery in the context of a lawsuit initiated by workers. ${ }^{131}$ Anti-SLAPP statutes only allow the dismissal of a lawsuit; in cases in which abusive litigation tactics take other forms, anti-SLAPP statutes cannot provide a remedy. Workers need protections within the litigation process itself that do not depend on which party initiated the suit.

Rest. Emps., 82 Cal. Rptr. 2d 10 (Ct. App. 1999); Fashion 21 v. Coal. for Humane Immigrant Rights of L.A., 12 Cal. Rptr. 3d 493, 496 (Ct. App. 2004); Magic Laundry Servs., Inc. v. Workers United Serv. Emps. Int'l Union, No. CV-12-9654-MWF AJWX, 2013 WL 1409530, at*1 (C.D. Cal. Apr. 8, 2013).

126. Opinion of the Justices (SLAPP Suit Procedure), 641 A.2d 1012, 1015 (N.H. 1994).

127. See, e.g., Joshua L. Baker, Chapter 338: Another New Law, Another SLAPP in the Face of California Business, 35 McGeorge L. REV. 409, 411 (2004) ("Those who are not necessarily opposed to SLAPP suits often ask the following questions: Doesn't the First Amendment's Petition Clause apply just as equally to the filer as it does to the target? Doesn't the Seventh Amendment guarantee filers 'the right of trial by jury'? Aren't there cases where the filers do not have any other choice but to sue, or where targets actually deserve to be sued? Certainly the answer to these questions is 'yes."').

128. See PRING \& CANAN, supra note 107 , at 11-12.

129. Davis v. Cox, No. 90233-0, 2015 WL 3413375, at*11 (Wash. May 28, 2015).

130. The Supreme Court may well be sympathetic to such a claim by employers. In Bill Johnson's Restaurants, Inc. v. NLRB, the Court limited the NLRB's ability to enjoin SLAPPs before the term had even been invented. 461 U.S. 731, 741 (1983) ("The right of access to a court is too important to be called an unfair labor practice solely on the ground that what is sought in court is to enjoin employees from exercising a protected right." (citing Peddie Buildings, 203 N.L.R.B. 265, 272 (1973))).

131. Anti-SLAPP statutes may still be relevant in lawsuits brought by workers to defend against frivolous counterclaims. 
III.

\section{LABOR ORGANIZING PRIVILEGE}

Thus far, this article has focused on defining the problem of abusive litigation tactics and arguing that other possible solutions to this problem are not effective at protecting workers' rights to organize and collectively bargain. Filing an NLRB unfair labor practice charge is slow and ineffective, and Supreme Court case law has limited what remedies are available to workers who are the victims of abusive litigation tactics. Moreover, workers who are exempt from the NLRA cannot file a charge at all. Anti-SLAPP statutes are important, but workers in states without them are unprotected, and recent legal developments suggest that they might be vulnerable to attack on constitutional grounds. Nor can they protect workers from abusive litigation tactics that do not take the form of the filing a lawsuit.

A labor organizing evidentiary privilege would avoid most of these problems while giving workers a strong tool in resisting employer abuses of the legal system. This Part lays out the different theoretical justifications for evidentiary privileges, proposes a new justification, and argues that a labor organizing privilege should be recognized pursuant to these justifications.

I embark on this project while recognizing that a labor organizing privilege would face several obstacles to gaining recognition. In general, privileges are "not favored" because they are seen as antithetical to the truth-telling function of courts. ${ }^{132}$ Although the Federal Rules of Evidence give federal courts authority to develop new common law evidentiary privileges, ${ }^{133}$ this authority has rarely been used. ${ }^{134}$ The Supreme Court has yet to adopt an evidentiary privilege that was not originally proposed by the Advisory Committee for the Rules of

132. See Ronald Goldfarb, In Confidence: When to Protect Secrecy and When to Require Disclosure 32 (2009). See also Univ. of Penn. v. E.E.O.C., 493 U.S. 182, 189 (1990) ("We do not create and apply an evidentiary privilege unless it promotes sufficiently important interests to outweigh the need for probative evidence .... Inasmuch as testimonial exclusionary rules and privileges contravene the fundamental principle that the public . . . has a right to every man's evidence, any such privilege must be strictly construed." (internal citations and quotations omitted)).

133. FED. R. Evid. 501 Advisory Committee's Note (“[T]he Committee, through a single Rule, 501, left the law of privileges in its present state and further provided that privileges shall continue to be developed by the courts of the United States under a uniform standard applicable both in civil and criminal cases."). See also S. REP. No. 93-1277, at 13 (1974), reprinted in 1974 U.S.C.C.A.N. 7051, 7059 (Rule 501 "should be understood as reflecting the view that the recognition of a privilege based on a confidential relationship . . . should be determined on a caseby-case basis.").

134. See, e.g., Univ. of Penn., 493 U.S. at 189 (rejecting peer review privilege); In re Sealed Case, 148 F.3d 1073 (D.C. Cir. 1998) (rejecting Secret Service privilege); United States v. Gillock, 445 U.S. 360 (1980) (rejecting state legislator privilege); United States v. Frederick, 182 F.3d 496, 500 (7th Cir. 1999) (rejecting accountant privilege); In re Grand Jury, 103 F.3d 1140 (3d Cir. 1997) (rejecting parent-child privilege); Hancock v. Dodson, 958 F.2d 1367 (6th Cir. 1992) (rejecting doctor-patient privilege). But see Jaffee v. Redmond, 518 U.S. 1 (1996) (recognizing psychotherapist privilege). 
Evidence in its first (rejected) draft to Congress, ${ }^{135}$ and the Court has in one case rejected a privilege the Advisory Committee included. ${ }^{136}$ Every federal court to consider a broad labor organizing privilege has rejected it. ${ }^{137}$

Likewise, the prospects for a labor organizing privilege established by federal statute are uncertain at best. Recent pro-labor legislation, such as the Employee Free Choice Act, died even when the Democrats had control of Congress. ${ }^{138}$ State legislatures have been somewhat more willing to adopt new privileges, ${ }^{139}$ but still rarely recognize privileges that did not exist at common law. ${ }^{140}$ Moreover, recent anti-union and anti-worker campaigns at the state level may make a labor organizing privilege a hard sell, especially in states without a strong union presence. ${ }^{141}$

Yet, there is reason to hope that a labor organizing privilege could gain traction. The recent successful state campaigns to raise the minimum wage have

135. The draft Rules of Evidence enumerated nine testimonial privileges, all of which previously existed at common law: privileges for required reports, communications between lawyer and client, communications between psychotherapist and patient, spousal testimony, communications to clergy, political vote, trade secrets, state secrets, and identity of an informer. See Proposed Rule of Evidence 501 Advisory Committee's Note, 56 F.R.D. 183, 230, 243-79 (1972).

136. Trammel v. United States, 445 U.S. 40 (1980) (rejecting adverse spousal testimony privilege).

137. See, e.g., Patterson v. Heartland Indus. Partners, Inc., 225 F.R.D. 204 (N.D. Ohio 2004); Parra v. Bashas' Inc., No. CIV 02-591-PHX RCB, 2003 WL 25781409 (D. Ariz. Oct. 2, 2003); Soc'y of Prof'l Eng'g Emps. in Aerospace v. Boeing Co., Nos. 05-1251-MLB, 07-1043-MLB, 2009 WL 3711599, at *6 (D. Kan. Nov. 3, 2009); Int'l Bhd. of Teamsters, Airline Div. v. Frontier Airlines, Inc., No. 11-CV-02007-MSK-KLM, 2012 WL 1801979 (D. Colo. May 16, 2012).

138. See Steven Greenhouse, Democrats Drop Key Part of Bill to Assist Unions, N.Y. TIMES (July 16, 2009), http://www.nytimes.com/2009/07/17/business/17union.html.

139. Raymond F. Miller, Creating Evidentiary Privileges: An Argument for the Judicial Approach, 31 ConN. L. REV. 771, 793 (1999). At the state level, evidentiary privileges were traditionally a matter of common law, but have recently become the province of state legislatures. 1 MCCormick on Evidence $§ 75$ (Kenneth S. Broun, George E. Dix, Edward J. Imwinkelried, David H. Kaye, Robert P. Mosteller, E.F. Roberts, Eleanor Swift eds., 7th ed. 2013). For a list of state statutes, see Edward Imwinkelried, The New Wigmore: A Treatise on Evidence app. D (2010).

140. For instance, California has established fourteen evidentiary privileges, eleven of which either existed at common law or were included in the Advisory Committee's 1972 draft rules. See CAL. Evid. CODE $\S \S 930-1063$ (West 2014). The three "new" privileges-sexual assault counselor-victim privilege, domestic violence counselor-victim privilege, human trafficking caseworker-victim privilege-are all extensions of the psychotherapist-patient privilege proposed by the 1972 draft rules.

141. See Scott Bauer, Wisconsin GOP Bypasses Dems, Cuts Collective Bargaining, AssociATED PRESS, Mar. 10, 2011, available at http://www.cleveland.com/nation/index.ssf/2011 /03/wisconsin_republicans_bypasses.html (discussing the repeal of collective bargaining rights in Wisconsin); Keith Naughton, John McCormick \& Chris Christoff, Michigan Right-to-Work Law Viewed as Domino Redefining Rust Belt, Pittsburgh Post-GazetTe (Dec. 16, 2012), http://www.post-gazette.com/news/nation/2012/12/16/Michigan-right-to-work-law-viewed-as -domino-redefining-Rust-Belt/stories/201212160208 (discussing right-to-work laws in traditional union strongholds such as Michigan). 
demonstrated a real appetite for pro-worker policy. ${ }^{142}$ And while a broad labor organizing privilege has been rejected by courts thus far, many courts have adopted a more limited union representative privilege, which protects communications between workers and union representatives in the context of disciplinary proceedings. ${ }^{143}$ These decisions show that courts, while hostile to evidentiary privileges generally, have in some contexts recognized the important relationship between workers and their representatives.

The following analysis focuses mostly on judicially created privileges, but many of the policy considerations interwoven into these justifications could be used to support legislatively created privileges as well. Indeed, a labor organizing privilege may initially need to gain traction with state legislatures before it becomes viable in federal court, as the recent examples of other privileges show. ${ }^{144}$

\section{A. Theoretical Justifications for Evidentiary Privileges}

Any discussion of evidentiary privileges must begin with the "instrumental" justification for evidentiary privileges endorsed by venerable evidence expert Dean John Henry Wigmore. Although Wigmore did not invent the instrumental justification, he is credited with precipitating its widespread acceptance among courts and scholars in the early twentieth century. ${ }^{145}$ Wigmore proposed a fourpart test for the recognition of evidentiary privileges: (1) the communications were made in confidence; (2) the element of confidentiality is essential to maintain the parties' relationship; (3) there is a community need to "sedulously" foster the relationship; and (4) the harm to the relationship caused by the disclosure would exceed any benefit from the correct disposal of the litigation. ${ }^{146}$ The Wigmore test remains the gold standard for courts today when they consider whether to recognize new evidentiary privileges. ${ }^{147}$

142. See Eric Morath, In a First, Vermont Sets Wage Floor Above \$10.10, WALL St. J., June 11, 2014, at A6; Monica Davey \& Kirk Johnson, Michigan Joins Move to Increase Hourly Wage, N.Y. TIMES, May 29, 2014, at A18.

143. See infra Part III.E.1.

144. In Jaffee $v$. Redmond, the Supreme Court recognized the psychotherapist-patient privilege only after all fifty states and the District of Columbia had done so. 518 U.S. 1, 2 (1996). Other privileges are in the process of gaining support through a state-by-state process. For example, the first state to recognize a privilege for communications between a victim and domestic violence counselor was California, in 1986. CAL. EvID. CODE $\S 1037.2$ (West 2014). Since then thirty-four states and the District of Columbia have adopted some version of the privilege. See Jeffrey R. Baker, Necessary Third Parties: Multidisciplinary Collaboration and Inadequate Professional Privileges in Domestic Violence Practice, 21 COLUM. J. GENDER \& L. 283, 332 n.145 (2011) (listing state statutes).

145. See 1 McCormick on Evidence $§ 72$ (Kenneth S. Broun, George E. Dix, Edward J. Imwinkelried, David H. Kaye, Robert P. Mosteller, E.F. Roberts, Eleanor Swift eds., 7th ed. 2013) ("Wigmore's views have been widely accepted by the courts, and have largely conditioned the development of thinking about privilege.").

146. 8 John Henry Wigmore, Evidence in Trials at Common LaW § 2285, at 527 (McNaughton rev. 1961). Wigmore openly criticized many existing privileges for failing to meet 
The central premise of the instrumental justification is that evidentiary privileges foster and encourage open communications, and, conversely, that the absence of the privilege chills such communications. It predicts that evidentiary privileges will have very little effect on the outcome of litigation, because most privileged communications would not otherwise come into existence if the parties to the communications know their communications will not be privileged. ${ }^{148}$ Wigmore believed evidentiary privileges should be rare, but absolute; anything short of an absolute privilege would fail to prevent the chilling effect central to the instrumental justification. ${ }^{149}$

Modern scholars have criticized the instrumental justification on the grounds that it is based upon an empirical hypothesis that is either untested or flawed. ${ }^{150}$ Most private communications, they argue, would occur regardless, either because most individuals are unaware of the privilege or because knowledge would not alter their behavior given the small chance that they will have to disclose their communications in court. ${ }^{151}$ A more fundamental critique of the instrumental justification is that it devalues intimate relationships by viewing them through the prism of litigation: "Is it not the intrinsically private character of the relation, and the reciprocal indecency of invading that privacy, rather than the parties' knowledge of the law of evidence, that chiefly justifies confidentiality?" 152 Or, as one treatise asks, "What kind of people are we who empower courts in our names to compel parents, friends, and lovers to become informants on those who have trusted them?"153

one or more of his conditions, including the doctor-patient privilege (for failing to meet the second and fourth conditions) and the priest-penitent privilege (for failing to meet the third condition). Id.

147. See, e.g., United States v. Zolin, 491 U.S. 554, 562-63 (1989) (recognizing that the rationale for privilege incorporates variants on Wigmore's four conditions); Jaffee, 518 U.S. at 910 (using a test that seeks to satisfy Wigmore's fourth condition); Swidler \& Berlin v. United States, 524 U.S. 399, 407-08 (1998) (discussing the importance of continued privilege posthumously to the attorney-client relationship).

148. See Melanie B. Leslie, The Costs of Confidentiality and the Purpose of Privilege, 2000 Wis. L. REV. 31, 31 (2000) ("In a perfect world, the privilege would shield no evidence. Privilege generates the communication that the privilege protects. Eliminate the privilege, and the communication disappears. . . [T] he privilege would protect only . . . statements that would not otherwise have been made."). The Supreme Court embraced this justification for evidentiary privileges in Jaffee $v$. Redmond, in which the Court recognized the psychotherapist-patient privilege, reasoning that "[i]f the privilege were rejected, confidential conversations between psychotherapists and their patients would surely be chilled [and] much of the desirable evidence to which litigants such as petitioner seek access . . . is unlikely to come into being." 518 U.S. at 12 .

149. Edward J. Imwinkelried, The New Wigmore: A Treatise on Evidence, Evidentiary PRIVILEGES § 5.4.4 (Richard Freedman ed., 2002) [hereinafter THE NEW WigMORE].

150. Edward J. Imwinkelried, Questioning the Behavioral Assumption Underlying Wigmorean Absolutism in the Law of Evidentiary Privileges, 65 U. PITT. L. Rev. 145, 156-73 (2004) (summarizing scholarship).

151. Id. at 180 .

152. Charles L. Black, Jr., The Marital and Physician's Privilege-A Reprint of a Letter to a Congressman, 1975 DuKE L.J. 45, 49 (1975).

153. 23 Charles Alan Wright \& Michael H. Graham, Federal Practice and Procedure: Federal Rules of Evidence $§ 5422.1$ (1st ed.). 
In response to these criticisms, several alternative "humanistic" approaches to Wigmore have sought to justify evidentiary privileges by reference to certain intrinsic values. Because humanistic justifications do not depend on the individual's reliance on confidentiality, privileges need not be absolute and can be subject to exceptions or a balancing of interests. ${ }^{154}$ One humanistic approach, proposed by Edward J. Imwinkelried, locates its justification in personal autonomy and decisional privacy. ${ }^{155}$ Individuals need to have the autonomy to seek expert advice without fear of disclosure, and courts should promote such advice-seeking by creating a "private zone."156 Unlike the instrumental justification, the personal autonomy approach does not rely on an account of how individuals behave. ${ }^{157}$ Instead, it seeks to protect certain categories of decisions - in matters of health, law, family and conscience, for example - that society has deemed important. ${ }^{158}$

In another variation of the humanistic justification, evidentiary privileges allow for the protection of certain relationships that society has deemed particularly important or deserving of protection. ${ }^{159}$ The spousal communications privilege is often justified on this ground, ${ }^{160}$ as are arguments for an expanded list of interpersonal privileges, such a parent-child privilege. ${ }^{161}$ Even the attorney-client privilege, perhaps the paradigmatic example of an instrumental privilege, has been justified on the grounds that requiring an attorney to "betray" a client is intrinsically wrong, regardless of the practical implications. ${ }^{162}$

154. Edward J. Imwinkelried, The New Wigmore: An Essay on Rethinking the Foundation of Evidentiary Privileges, 83 B.U. L. REv. 315, 337 (2003).

155. THE NeW WigmORE, supra note 149 , at $\S$ 5.3.3.c.

156. Id.

157. The distinction between the "instrumental" and "humanistic" justifications are somewhat blurred. As Wright and Graham point out, "[b]ecause every legal rule is an instrument to bring about the result it commands (or forbids), there is a sense in which all legal rules are instrumental." 23 WRIGHT \& GRAHAM, supra note 153, at $\$ 5422$.

158. Imwinkelried, supra note 154 , at 328.

159. See, e.g., Black, supra note 152, at 51 (" $[\mathrm{M}]$ any human interests are more important than the conduct of whatever litigation may from time to time arise."); David Louisell, Confidentiality, Conformity, and Confusion: Privileges in Federal Court Today, 31 Tul. L. ReV. 101, 113 (1956).

160. Anne N. DePerez, Pillow Talk, Grimgribbers and Connubial Bliss: The Marital Communication Privilege, 56 IND. L.J. 121, 122 (1980) ("The function of privileges is to foster or safeguard certain relationships or interests which are considered so important that their protection justifies the exclusion of facts from evidence which are both relevant and reliable.").

161. Yolanda L. Ayala \& Thomas C. Martyn, To Tell or Not to Tell? An Analysis of Testimonial Privileges: The Parent-Child and Reporter's Privileges, 9 St. JoHN's J. LeGAL Comment. 163, 176 (1993); Jeffrey Begens, Parent-Child Testimonial Privilege: An Absolute Right or an Absolute Privilege?, 11 U. Dayton L. Rev. 709, 719-20 (1986); Amee A. Shah, The Parent-Child Testimonial Privilege-Has the Time for It Finally Arrived?, 47 CLEV. ST. L. REv. 41, 45-46 (1999).

162. 23 Wright \& GRAhAM, supra note 153 , at $§ 5422$; Richard C. Wydick, The AttorneyClient Privilege: Does It Really Have Life Everlasting?, 87 KY. L.J. 1165, 1174 (1999) ("Primarily [the communications privileges] are a right to be let alone, a right to unfettered freedom, in certain 
Some evidentiary privileges may find justification in the Constitution as well. The clearest example of a constitutionally required evidentiary privilege is the privilege against self-incrimination. ${ }^{163}$ In addition, many scholars have made quasi-constitutional arguments in support of certain common law privileges such as the marital communications privilege, the doctor-patient privilege, and the priest-penitent privilege. ${ }^{164}$ The idea that a person is entitled to a zone of privacy that protects his or her most intimate relationships from scrutinycentral to the humanistic justification-also echoes the constitutional right to privacy first recognized in Griswold $v$. Connecticut and may provide independent justification for these privileges. ${ }^{165}$ Similarly, as discussed below, the First Amendment has spawned a number of privileges, including a privilege to protect freedom of association and the still-developing reporter-source privilege rooted in the freedom of the press. ${ }^{166}$

Finally, the power justification seeks to explain why certain privileges were recognized at common law by reference to the political or socio-economic power of those the privileges protect. ${ }^{167}$ This justification has a certain intuitive appeal; the word "privilege" itself evokes an image of a protected elite. ${ }^{168}$ When viewed through a socio-economic lens, the traditional evidentiary privileges begin to look like a "who's who" list of the privileged class. Thus, the power justification tells us that professionals such as lawyers (but usually not accountants) and doctors $^{169}$ (but usually not nurses) are protected not because they meet any objective test, but because lawyers and doctors have expended political capital to

narrowly prescribed relationships, from the state's coercive or supervisory powers and from the nuisance of its eavesdropping." (internal citations omitted)).

163. Chavez v. Martinez, 538 U.S. 760, 770 (2003) (describing the right against selfincrimination as "an evidentiary privilege that protects witnesses from being forced to give incriminating testimony").

164. See Black, supra note 152, at 47; Earl C. Dudley, Jr., Federalism and Federal Rule of Evidence 501: Privilege and Vertical Choice of Law, 82 GEO. L.J. 1781, 1818 (1994) ("To the extent one adopts an expansive view of the role of the Constitution in protecting individual privacy, it is tempting to find constitutional underpinnings for evidentiary privileges.").

165. 381 U.S. 479, 485-86. See also Black, supra note 152, at 48.

166. See infra Part III.D.

167. Developments in the Law: Privileged Communications, 98 HARV. L. Rev. 1450, 1493 (1985); 23 WRIGHT \& GRAHAM, supra note 153, at $\S 5422$ ("In a society with egalitarian pretensions, the creation and justification of a privilege to refuse to respond to a judicial inquiry is essentially a political question; i.e., it is an allocation of power as between the various components of the society."); Kit Kinports, The "Privilege" in the Privilege Doctrine, in FEMINIST PersPeCtives ON EVIDENCE 82 (Childs ed., 2000) ("Not surprisingly, those who make these value judgments - the predominantly male legislatures and judiciary-do so in a way that mirrors their own values. ... As a result, the law of privileges as applied has tended to favour the professions that are dominated by men and that serve wealthier clientele.").

168. Developments in the Law, supra note 167, at 1494; GOLDFARB, supra note 132, at 34 ("Is the very notion of privilege elitist?").

169. There is no federally recognized physician-patient privilege, see, e.g., United States v. Bek, 493 F.3d 790 (7th Cir. 2007), but it exists in many states, see, e.g., AlASKA R. EvID. 504;

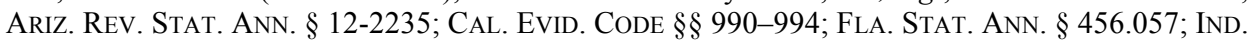
Code ANN. § 34-46-3-1(2); Mich. STAT. ANN. §§ 27A.2157, 28.945(2); N.Y. C.P.L.R. 4504. 
ensure that their communications are privileged. ${ }^{170}$ Religious institutions have historically been very powerful; hence the clergy-congregant privilege is recognized. ${ }^{171}$ Though professional privileges are typically framed as a benefit to the one seeking professional advice, a more skeptical explanation is that professionals see evidentiary privileges as a way to protect their own secrets. ${ }^{172}$ Likewise, the spousal privileges, while often justified today on privacy or intimacy grounds, historically came into being to protect a husband from the indignity of his wife, not yet a separate legal person, testifying against him. ${ }^{173}$ Corporate $^{174}$ and government secrets ${ }^{175}$ are well-protected, while those on the other end of the socio-economic spectrum are exposed. "[T]he poor man's only privilege is perjury." $" 176$

The power justification is descriptive, not normative, but its critique of privilege law could form the basis of a democratic and egalitarian alternative to instrumental and humanistic justifications. An egalitarian justification would support the recognition of evidentiary privileges that, instead of reinforcing existing power structures, are designed to protect the most vulnerable. ${ }^{177}$ It would embrace, rather than obscure, the fact that "[1]egal secrets are strategic tools of power" "178 and that "[k]nowledge may not be power . . . but it is often important in the accumulation and exercise of power." 179

Of the existing evidentiary privileges, an egalitarian justification would be most skeptical of government and corporate privileges, since these institutions already have considerable advantages in keeping secrets. The professional privileges might be expanded to include communications to professionals such

170. Kinports, supra note 167, at 84-93.

171. Developments in the Law, supra note 167, at 1556 ("The paucity of challenges to the clergy-communicant privilege may result from the legal system's respect for the clergy and for established religion.").

172. See Sissela BoK, Secrets: On the Ethics of Concealment and Revelation 131 (1982) (noting that professionals can use confidentiality "here as elsewhere, as a shield for activities that could ill afford to see the light of day").

173. WigMORE, supra note 146 , at $\$ 2227$.

174. For example, the trade secrets privilege protects corporate intellectual property from disclosure. See GOLDFARB, supra note 132, at 156.

175. For example, the state secrets privilege provides the government with a powerful tool to prevent disclosure of a broad swath of government conduct. See Nicole Hallett, Protecting National Security or Covering Up Malfeasance: The Modern State Secrets Privilege and Its Alternatives, 117 YALE L.J. POCKET PART 82 (2007), http://thepocketpart.org/2007/10/01/hallett .html.

176. 23 WRIGHT \& GRAHAM, supra note 153 , at $§ 5422$.

177. Some states have recognized privileges that protect particularly vulnerable individuals. For instance, California has statutory privileges protecting sexual assault, domestic violence, and trafficking victims from disclosing communications with their counselors. See CAL. EvID. CODE $\S \S 1035,1037.5,1038$ (West 2014).

178. GOLDFARB, supra note 132, at 10.

179. Kim Lane Scheppele, Legal Secrets: Equality and EfFiciency in the Common Law 23 (1988). See also BoK, supra note 172, at 282 ("Control over secrecy and openness gives power: it influences what others know, and thus what they choose to do."). 
as tax advisors, social workers, and nurses with whom low-income individuals are more likely to come into contact. The clergy-congregant privilege might be limited or rejected. How would the proposed labor organizing privilege fare under the various justifications? This article argues that the labor organizing privilege satisfies the Wigmore test. But strong arguments also exist for a labor organizing privilege based on humanistic and egalitarian justifications. That workers are entitled to a certain amount of personal autonomy in their relationship with their fellow workers and representatives is a value embedded in the NLRA. The egalitarian justification provides a basis that is stronger stillthe power imbalance inherent in the employer-employee relationship makes a compelling case for protection pursuant to egalitarian principles. Finally, there may be constitutional arguments for the adoption of a labor organizing privilege under the First and Thirteenth Amendments to the U.S. Constitution.

\section{B. The Wigmore Test}

The instrumental justification is still the dominant paradigm in American privilege law, and any potential privilege must satisfy the Wigmore test. As illustrated below, the labor organizing privilege fulfills all four Wigmore factors.

\section{The Communications Were Made in Confidence}

As is the case with other evidentiary privileges, a labor organizing privilege would only reach communications where there was a reasonable expectation of confidentiality by the parties. ${ }^{180}$ There is evidence that workers and labor organizations intend at least some of their communications to be confidential. ${ }^{181}$ As one court reasoned:

It is self-evident that when a union member goes to a closed union meeting for the purpose of discussing his or her legal rights against the employer, or the employer's suppliers or contractors, for injuries resulting from working conditions on the employer's premises, the member rationally would expect that any statements made concerning the legal problem would remain confidential. The fear of possible employer retribution would compel a reasonable expectancy of privacy on the

180. 1 MCCORMICK, supra note 145 , at $\S 72$ (requiring for all privileges that " $\mathrm{t}] \mathrm{he}$ communications must originate in a confidence that they will not be disclosed" (quoting 8 WigMORE, supra note 146, at $\S 2285$ )); United States v. Mejia, 655 F.3d 126, 132 (2d Cir. 2011) (attorney-client privilege applies to communications "that are intended to be, and in fact were, kept confidential”); United States v. Auster, 517 F.3d 312, 315 (5th Cir. 2008) (“As a matter of law, where the confidentiality requirement has not been satisfied, the psychotherapist-patient privilege - as with other privileges - does not apply.").

181. See M. Koppel Co., 166 N.L.R.B. 975, 978 (1967) (noting that it is "common practice among labor organizations who attempt to keep information received in connection with membership applications or authorization cards as confidential as possible"). 
member's part, particularly where only fellow workers and the union attorneys are present. ${ }^{182}$

This assumption of confidentiality is borne out in the words and actions of workers and labor organizers. Union manuals, for instance, emphasize the importance of confidentiality, particularly early in organizing campaigns. ${ }^{183}$ The American Federation of State, County \& Municipal Employees ("AFSCME") Organizing Model \& Manual provides perhaps the clearest declaration of this strategy, advising organizers that they must "constantly stress the need for secrecy" to workers. ${ }^{184}$ Unions and worker centers often ask workers to sign confidentiality agreements or take other proactive steps to protect confidentiality before inviting new workers to meetings. For similar reasons, unions have supported the Employee Free Choice Act ("EFCA"), which would allow an alternative to NLRB-certified elections if the union collects signatures of a majority of workers (also called "card check"). ${ }^{185}$ Card check "enables employees to conduct union organizing campaigns without giving notice to management that a campaign is underway and thus to limit, or avoid entirely, managerial intervention." ${ }^{186}$ In other words, card check acts as a secrecy device that enables unions to keep their organizing confidential. ${ }^{187}$

This emphasis on confidentiality exists largely because labor organizing is so perilous for workers. The risk of retaliation is high. According to a study by Kate Bronfenbrenner, employers discharge union supporters in thirty-four

182. Benge v. Superior Court, 182 Cal. Rptr. 275, 281 (Ct. App. 1982).

183. See, e.g., How to Organize a Union, COMMC'N Workers OF AM., http://www.cwa-union .org/pages/how_to_organize_a_union (last visited Dec. 20, 2013) ("When talking among yourself about a union, be sure to talk only while you are on breaks, away from work areas, or off company property. Organizing a union is legal and a protected right under the law, but you need to avoid tipping off management as long as possible. If your employer finds out, especially when you are in the beginning stages of identifying key workplace issues and building union support, your road to success will be much more difficult."); INTERNATIONAL BOARD OF TEAMSTERS ORGANIZING GUIDE 9 (“[T]he organizer's work is totally underground.").

184. Am. Fed’n of State, Cnty. \& Mun. Emps., Organizing Model \& Manual 1-6 (1999) (cited in Benjamin Sachs, Enabling Employee Choice, A Structural Approach to the Rules of Union Organizing, 123 HARV. L. REV. 655, 665 (2010)).

185. Employee Free Choice Act, H.R. 1409, 111 th Cong. § 2(6) (2009).

186. See Sachs, supra note 184 , at 671.

187. Privacy, confidentiality, and secrecy are distinct concepts and all three may inform whether a particular communication should be subject to an evidentiary privilege. See GOLDFARB, supra note 132, at 19-21. The term privacy is used to "describe general demands for anonymity, control over one's identity, self-determination, ownership of personal data and the right to be left alone." Id. at 22. Confidentiality refers to the obligations of others to protect one's privacy. Id. at 20. Secrecy is the act of not disclosing, whether or not the information is private or confidential. When a child tells her friend not to disclose something because "it's secret," what she actually means is that it is confidential. It is only secret as long as her friend keeps her confidences. Likewise, one can have a secret that is not private. The fact that one robbed a bank yesterday is surely something one wishes to keep secret, but one has no right to privacy in that information. Confidentiality intersects with privacy and secrecy only insofar as there is an obligation on the part of the listener to refrain from disclosing. Although Wigmore was more concerned with confidentiality, the humanistic justification sees privacy as a paramount value. 
percent of NLRB-supervised organizing campaigns, ${ }^{188}$ and there is reason to believe this percentage is even higher in a non-union context. In organizing campaigns with a majority of undocumented workers, half of all employers make threats of referral to Immigration and Customs Enforcement ("ICE"), and seven percent actually follow through on their threats. ${ }^{189}$ Other employer tactics include verbal abuse (forty-one percent), alteration of benefits or working conditions (twenty-two percent), and layoffs (five percent). ${ }^{190}$ Fifty-four percent of employers waged "aggressive" campaigns consisting of the use of ten or more anti-organizing tactics. ${ }^{191}$ These anti-organizing tactics are in addition to the retaliatory litigation tactics discussed earlier in this article. ${ }^{192}$

Confidentiality may also exist as part of the fiduciary duty that union representatives owe to workers under the NLRA. ${ }^{193}$ This duty may arguably prohibit union representatives from revealing confidential communications with workers they represent, absent a court order. ${ }^{194} \mathrm{~A}$ union representative forced to choose between testifying about confidential communications and being held in contempt may choose the latter. ${ }^{195}$

188. BRONFENBRENNER, supra note 13, at 2. Bronfenbrenner's study reviewed source documents from 1004 NLRB elections that took place between January 1, 1999, and December 1, 2003, as well as in-depth studies of 562 campaigns from within that sample. Id. at 1.

189. Id. at 12 .

190. Id.

191. Id. at 11. Other studies have found similar levels of retaliation by employers. See, e.g., Chirag Mehta \& Nik Theodore, Undermining the Right to ORganize: EMPlOYer Behavior DURING UNION REPRESENTATIVE CAMPAIGNS 5 (2005) (finding that thirty percent of employers fired workers for engaging in organizing activities during one period of time in the Chicago metropolitan area).

192. See supra Part I.

193. See 29 U.S.C. § 501(a) (2012) ("The officers, agents, shop stewards, and other representatives of a labor organization occupy positions of trust in relation to such organization and its members as a group. It is, therefore, the duty of each such person, taking into account the special problems and functions of a labor organization, to ... refrain from dealing with such organization as an adverse party or on behalf of an adverse party in any matter connected with his duties . ..."); Int'1 Bhd. of Elec. Workers, 309 N.L.R.B. 856, 857 (1992) ("It is well settled that a union owes a fiduciary duty to employees it represents as the exclusive collective-bargaining representative.").

194. See, e.g., Am. Airlines, Inc. v. Superior Court, 8 Cal. Rptr. 3d 146, 149 (Ct. App. 2003) (union representative argued that requiring him to testify about confidential communications with union members would create a conflict of interest). Non-union organizers are not bound by these same rules, although some commentators have argued that they should be. See, e.g., Marculewicz \& Thomas, supra note 58 , at 79 .

195. In Privileged Communications: Developments in the Law, the author observes that "privilege holders seem to constitute those groups most likely to respond to a court order by lying or by refusing to testify. They are bound by strong loyalties or oaths of confidentiality, often supported by professional codes of ethics and the threat of professional sanctions." 98 HARV. L. REV. at 1499. Thus, privileges exist to avoid the embarrassment to the legal system of either ignoring a witness's perjury or refusal to testify or throwing the witness in jail. Id. Although union representatives are not subject to the same type of professional code as attorneys and medical professionals, they do have legal obligations towards the workers they represent, as well as strong loyalties. 
Non-union organizers and workers have no similar legal obligation under current law, but the absence of a legal duty is not dispositive. ${ }^{196}$ On the contrary, the potential adverse consequences that workers face give them ample reason to keep their communications confidential. For example, a worker interviewed for a report for American Rights at Work, a union-backed non-profit organization, described how confidentiality among the workers was critical to protecting themselves from retaliation by their employer:

The first time the owner learned about the campaign, the boss started looking for the leaders. He started asking everyone who the leader was. We all kept very quiet. We didn't want him to know who the leadership was. He will fire the guys, he doesn't care. To try and figure out who was for the union, the owner printed up T-shirts for workers to wear that said "no union." So we all wore the T-shirts . . . to keep the identity of the leaders a secret. ${ }^{197}$

Not every communication between workers is confidential, nor is every conversation between workers about labor organizing or collective bargaining. Most communications will concern the work itself or mundane water-cooler talk that does not deserve special protection. A labor organizing privilege would be limited to relatively few communications that directly implicate workers' right to organize and collectively bargain. ${ }^{198}$ Limited in this way, the privilege would only cover communications made in confidence and, thus, would meet the first part of the Wigmore test.

\section{The Element of Confidentiality Is Essential to Maintain the Parties' Relationship}

At its core, the second factor of Wigmore's test asks whether the communications in question would be chilled without an evidentiary privilege. Since no jurisdiction has recognized a labor organizing privilege, the extent of any current chilling of communications regarding labor organizing and collective bargaining is difficult to ascertain.

However, common sense suggests that workers rationally fear that participating in an organizing campaign could lead them to suffer adverse consequences, such as losing their job or being deported. Without assurances

196. For instance, the marital communications privilege exists despite the fact that a spouse has no legal duty to keep marital communications confidential.

197. MEHTA \& THEODORE, supra note 191, at 19.

198. A labor organizing privilege would not be alone among evidentiary privileges in requiring a court to look to the purpose for which a communication was made. For instance, the priest-penitent privilege requires courts to look to whether the communication was made "for the purpose of obtaining spiritual aid or religious or other counsel, advice, solace, absolution, or ministration." Paul F. Rothstein \& Susan W. CRump, Federal Testimonial Privileges $§$ 10:3 ( 2 d ed. 2014). Likewise, the physician-patient privilege generally only applies to communications "for the purpose of diagnosis or treatment." Id. § $3: 1$. 
that their conversations with organizers or other workers will remain confidential, many workers may choose not to engage in the conversations at all. Once an organizing campaign is public, confidentiality remains important. Employers frequently retaliate against workers who support the campaign, ${ }^{199}$ and also seek to interrogate them about their organizing activities. ${ }^{200}$ Workers who know that an employer could compel co-workers to testify in court regarding their involvement in the campaign may be much less likely to participate.

Finally, confidentiality during collective bargaining is necessary to maintain the integrity of the bargaining process. As the NLRB has noted, "[i]f collective bargaining is to work, the parties must be able to formulate their positions and devise their strategies without fear of exposure. This necessity is so self-evident as apparently never to have been questioned." 201 The right to confidentiality in the civil settlement context, in which the attorney-client privilege generally applies, is well-established for precisely the same reason. ${ }^{202}$ If one party could question another party about their settlement strategy during a deposition, for example, the result would be disastrous for the settlement process.

Given the contentious nature of most labor organizing campaigns, they are much more likely to result in litigation than in cases of other communications protected by privileges, such as the spousal communications privilege $e^{203}$ and the doctor-patient privilege. ${ }^{204}$ It is therefore even more essential to the relationship among workers and between workers and their representatives to protect their communications from disclosure. This is so even though the possibility of litigation in any particular labor dispute is uncertain, and a worker may fear voluntary disclosure by another worker absent a court order. But the same could be said for these other privileges. ${ }^{205}$ The second Wigmore factor does not require that all risk of disclosure be mitigated by the privilege, merely that confidentiality be important to the integrity of the relationship. That is undoubtedly the case with the labor organizing privilege.

\footnotetext{
199. See supra notes $127-30$.

200. BRONFENBRENNER, supra note 13, at 10 (noting that employers use coercive interrogation in sixty-four percent of organizing campaigns).

201. Berbiglia, Inc., 233 N.L.R.B. 1476, 1495 (1977). See also Seelig v. Shepard, 578 N.Y.S.2d 965, 966 (N.Y. Sup. Ct. 1991) (Subpoenaing union leader "would necessarily breach the zone of confidentiality that must exist between union members and their leaders, and, insofar as the interrogation touched upon negotiations, would produce a chilling effect on future labor negotiations and the associational rights of union members.").

202. See BoK, supra note 172, at 182 (discussing the importance of secrecy to negotiations).

203. See Richard Lempert, The Economic Analysis of Evidence Law: Common Sense on Stilts, 87 VA. L. REV. 1619, 1690 (2001) (arguing that there is no evidence that marital communications would be chilled in the absence of an evidentiary privilege).

204. See THE New Wigmore, supra note 149, at $\S 6.2 .6$ (a) ("It is doubtful that the patient needs any additional inducement to speak freely, especially because in many cases the thought of a lawsuit has not yet crossed the patient's mind.”).

205. Indeed, this observation forms the basis of many of the critiques of the instrumental justification. See Imwinkelried, supra note 150, at 156-73.
} 


\section{There Is a Community Need to Sedulously Foster the Relationship}

Whether a relationship should be "sedulously fostered" is by necessity a policy question of whether society values a particular relationship enough to afford it special status under the law. With respect to some relationships, such as between spouses, courts and legislatures have answered in the affirmative. For other relationships, such as between parent and child, most jurisdictions have not. ${ }^{206}$ Should the relationship between workers be "sedulously fostered" in the same manner as the relationships protected by existing evidentiary privileges?

The first place to look for an articulated national policy is the NLRA itself. Section 7 of the NLRA (also called the "Wagner Act") grants workers sweeping labor rights:

Employees shall have the right to self-organization, to form, join, or assist labor organizations, to bargain collectively through representatives of their own choosing, and to engage in other concerted activities for the purpose of collective bargaining or other mutual aid or protection. ${ }^{207}$

The NLRA Preamble contains an even more explicit statement of national policy:

It is hereby declared to be the policy of the United States to . . protect[] the exercise by workers of full freedom of association, self-organization, and designation of representatives of their own choosing, for the purpose of negotiating the terms and conditions of their employment or other mutual aid or protection. ${ }^{208}$

The remainder of the Act is designed to enforce these policy objectives. Thus, section 8 delineates unfair labor practices of both employers and labor organizations designed to "interfere with, restrain, or coerce employees in the exercise of the rights guaranteed in [section 7]"209 and obligates employers to bargain in good faith with the workers' chosen representative. ${ }^{210}$ The NLRA not only articulates broad rights enjoyed by workers to organize and collectively bargain, but also provides enforcement mechanisms to ensure that these rights are secured. ${ }^{211}$

206. Id. $\S 6.2 .2$ ("Although the spousal privilege enjoys virtually universal support in the United States, only a small minority of U.S. jurisdictions recognize a parent-child privilege.").

207. 29 U.S.C. $\S 157$ (2012).

208. Id. $\S 151$ (2012). See also id. (referencing " $[\mathrm{t}]$ he denial by some employers of the right of employees to organize").

209. Id. § 158 (a) (2012).

210. Id. $\S 158(\mathrm{~d})$ (2012).

211. As explained in Part II.A, the NLRB has largely failed in fulfilling its objective of securing workers' section 7 rights. This failure, however, does not change the underlying policy of the NLRA. 
While later amendments to the NLRA, most notably the Taft-Hartley Act, ${ }^{212}$ were clearly intended to fix what critics saw as the one-sided nature of the Wagner Act, ${ }^{213}$ the central provisions and policy of the NLRA remained unchanged. ${ }^{214}$ The Taft-Hartley Act primarily regulated unions and union conduct. ${ }^{215}$ While such provisions could be properly characterized as anti-union, they were still ostensibly pro-worker. For instance, the language added to section 7 , which gives workers the right to refrain from any and all rights enumerated in the section, is specifically framed in terms of worker empowerment. ${ }^{216}$ The legislative history of the Taft-Hartley Act confirms that the new restrictions on unions were not intended, at least explicitly, to change the central policy of the NLRA, but rather to reign in what Congress saw as the abuses of unions. ${ }^{217}$ Given this clear national policy of protecting worker self-organization, it is a short leap to a labor organizing privilege. The reason is simple-the current avenues for protecting section 7 rights are not adequate to protect workers' labor rights. ${ }^{218}$ If one is serious about protecting workers' rights, then one must seriously consider a labor organizing privilege.

A conclusion that the relationship between workers and organizers or union representatives should be "sedulously fostered" will quickly become entangled in politics. But there is no reason that this needs to be the case. Even anti-union advocates believe that workers should be able to make intelligent choices about whether to collectively bargain, which an evidentiary privilege permits them to do. ${ }^{219}$ The privilege would be held by the worker, not the labor organization or representative. $^{220}$ If a union or worker center were acting against the interests of

212. Labor Management Relations (Taft-Hartley) Act, Pub. L. No. 80-101, 61 Stat. 136 (1947).

213. John E. Higgins, Jr., Peter A. Janus, Barry J. Kearney, W.V. "Bernie" Siebert \& KenNeth L. WAgNeR, THE DEVELOPING LABOR LAW 41 (2006).

214. Charles J. Morris, How the National Labor Relations Act Was Stolen and How It Can Be Recovered: Taft-Hartley Revisionism and the National Labor Relations Board's Appointment Process, 33 BERKELEY J. EMP. \& LAB. L. 1, 7 (2012) ("Although Taft-Hartley drastically curtailed the economic power of unions in the collective-bargaining process and complicated the Labor Board's administrative procedures, it nevertheless preserved all of the original Act's substantive provisions that protected the right of employees to unionize and engage in collective bargaining and even added new statutory language to re-emphasize this policy.").

215. Id. at 24 .

216. 29 U.S.C. $\S 157$ (2012) (“[Employees] shall also have the right to refrain from any or all of such activities except to the extent that such right may be affected by an agreement requiring membership in a labor organization as a condition of employment.").

217. Morris, supra note 214, at 24-30.

218. See supra Part II.

219. See, e.g., Richard Epstein, The Case Against the Employee Free Choice Act 44 (2009) (arguing against the EFCA on the grounds that it inhibits worker choice).

220. One could envision a privilege that could be invoked both by workers and their representatives, similar to the priest-penitent privilege in some states. See, e.g., CAL. EvID. CODE $\S 1034$ (West 2003) (recognizing separate privilege of clergy to refuse to disclose "penitential communications"); KAN. STAT. ANN. § 60-429 (protecting penitential communications if "the witness is the penitent or the minister"). Indeed, such a privilege would have the benefit of further protecting workers from employer coercion-an employer may attempt to coerce a worker into 
a worker, the worker could waive the privilege. Likewise, the privilege could be waived when an organizer or union official purported to represent a group of workers but in fact did not.

Admittedly, adopting a labor organizing privilege would redistribute power in organizing and collective bargaining to workers and their representatives and away from employers. It might also enhance the influence of unions and nontraditional labor organizations, although it would do so only indirectly through the added protection it would bestow on workers. Evidentiary privileges by their very nature redistribute power to the class of persons who owns them. A labor organizing privilege would be no different. Yet, rather than counseling against a labor organizing privilege, this fact should lend further support in favor of it. Such a redistribution of power is in line with eight decades of national policy that has had such redistribution as its explicit goal. ${ }^{221}$

\section{The Harm to the Relationship Caused by the Disclosure Would Exceed Any Benefit from the Correct Disposal of the Litigation}

A labor organizing privilege would have a minimal effect on the truthtelling function of the justice system. First, as a practical matter, communications concerning labor organizing and collective bargaining are often peripheral to the central issues in a case. In wage-and-hour cases, for example, employers typically make two arguments for why this evidence is relevant to the workers' claims. The first is that the employer needs a list of employees involved in the organizing campaign to identify individuals to depose. ${ }^{222}$ The second is that employers want to use the evidence obtained to advance the theory that the wage-and-hour violations have been fabricated by a meddling union or worker center for financial gain. ${ }^{223}$ For the former, if communications between workers are privileged, then this rationale falls away as a legitimate aim. The latter justification primarily concerns motive and credibility, which, while

waiving the privilege if the representative cannot invoke it independently. However, the legal justification for recognizing a labor organizing privilege that protects workers' representatives is not nearly as strong as the justifications for a privilege that protects workers themselves. The NLRA's objective is to protect the rights of workers, not the rights of labor organizations. Labor organizations, like employers, can commit unfair labor practices and inhibit the exercise of workers' labor rights. See 29 U.S.C. $§ 158$ (2012). In fact, the NLRA is agnostic as to whether workers join labor organizations or not. $I d$. $\S 157$. Furthermore, the political opposition to such a privilege would likely be insurmountable.

221. See 29 U.S.C. $\$ 151$ (2012) (identifying "[t]he inequality of bargaining power" between workers and employers as a problem the NLRA was intended to remedy).

222. See, e.g., Int'1 Union v. Garner, 102 F.R.D. 108, 116 (M.D. Tenn. 1984) (finding an employer seeking union membership cards to justify discovery on the grounds of witness identification).

223. See, e.g., Century Rest. \& Buffet, Inc., 358 N.L.R.B. No. 23, at *28 (Mar. 27, 2012) (finding an employer's counsel justified in coercive interrogation about union activities "in order to determine if the employees entered into any illegal financial agreements with the Union in bringing their case"). 
certainly relevant, are not sufficiently central to the case to overcome the workers' interest in keeping communications confidential.

In the case of litigation brought by employers, the evidence may be more directly relevant to the employer's claims. For instance, communications potentially covered under a labor organizing privilege may be helpful for an employer to meet its burden of proving negligence, reckless disregard, or knowledge for defamation claims. ${ }^{224}$ If carefully cabined, however, a labor organizing privilege would exclude only a small portion of the evidence available to an employer to prove its claim. For instance, a conversation between workers concerning a purported false statement, if not directly related to organizing strategy, would not be covered under the privilege. Nor would the employer be prohibited from relying on circumstantial evidence to show that the worker or organizer knew or suspected that the statement was false.

Moreover, there may be ways of limiting the privilege that take into account these concerns, for instance, by recognizing a crime-fraud exception to the privilege, or by adopting a qualified privilege that allows an employer to argue that the privilege should not apply in a particular case. ${ }^{225}$ Some of these potential limitations are discussed in Part IV.

\section{Humanistic and Egalitarian Justifications}

A labor organizing privilege justified on decisional autonomy or privacy grounds may seem inapposite. Work is not traditionally cited as an area of our personal lives that deserves special protection in the same category as "health, law, family, and conscience." 226 But perhaps it should be. A worker's decisions regarding whether to join a union, act collectively with his or her co-workers, or negotiate with an employer over wages and other conditions of employment are central to the employment relationship. And the importance of the employment relationship in an individual's life can hardly be understated. ${ }^{227}$ Most workers spend at least a third of their lives at work, and many low-wage workers spend much more.

It has long been recognized that work is central to human dignity. The International Labor Organization, for instance, has recognized a right to work "in conditions of freedom and dignity." 228 The NLRA, which gave individuals

224. RESTATEMENT (SECOND) OF TORTS $§ 613(1)(\mathrm{g})$ (1977).

225. As discussed above, a strict application of the Wigmore test would foreclose the possibility of a qualified privilege. If the privilege were recognized either under the U.S. Constitution or pursuant to humanistic or egalitarian justifications, then a qualified privilege is possible and, indeed, may have some advantages. See infra Part IV.

226. Imwinkelried, supra note 154, at 328.

227. See Cynthia Estlund, Working Together 7 (2003) ("The workplace is the single most important site of cooperative interaction and sociability among adult citizens outside the family.").

228. Declaration Concerning the Aims and Purposes of the International Labour Organization art. 2(a) (Oct. 9, 1946), 15 U.N.T.S. 35. See also Declaration on Fundamental Principles and 
special rights in the workplace that they do not enjoy in other forums, also implicitly recognizes the special status of work. A labor organizing privilege would be one powerful way to recognize the importance of work to our livelihood and happiness.

A labor organizing privilege is on even stronger ground if based on egalitarian principles. The power imbalance between workers and their employers is vast. Both the preamble and the legislative history of the NLRA make clear that one of the central purposes of the NLRA was to remedy this imbalance. The preamble identifies " $[\mathrm{t}]$ he inequality of bargaining power between employees who do not possess full freedom of association or actual liberty of contract, and employers who are organized in the corporate or other forms of ownership association" as a driving force behind the legislation. ${ }^{229}$ This redistributive purpose is echoed in the Senate Report, which states that a "major objective of the bill is to encourage, by developing the procedure of collective bargaining, that equality of bargaining power which is a prerequisite to equality of opportunity and freedom of contract." 230

We want evidentiary privileges to protect the most vulnerable, not the most powerful. A labor organizing privilege is an obvious way to provide this protection. Employers have many tactics they use to thwart worker organizing. A worker has few resources to defend him- or herself against employer abuse, retaliation, and harassment. Given that inequality, our stated national policy of remedying that inequality, and the failure of other remedies to adequately protect workers, a labor organizing privilege is one of the few protections available to empower workers to exercise their rights.

Rights at Work and Its Follow-Up, INT'L LABOUR ORG. (June 18, 1998), http://www.ilo.org /declaration/thedeclaration/textdeclaration/lang--en/index.htm ("[T]he guarantee of fundamental principles and rights at work is of particular significance in that it enables the persons concerned ... to achieve fully their human potential."). This right has roots in Catholic theology and is still espoused by religious groups today. See, e.g., The Dignity of Work and the Rights of Workers, U.S. CONFERENCE OF CATHOLIC BiSHOPS, http://www.usccb.org/beliefs-and-teachings/what-we-believe /catholic-social-teaching/the-dignity-of-work-and-the-rights-of-workers.cfm. Work is central to human dignity.

229. 29 U.S.C. $\S 151$ (2012).

230. S. Rep. 573, 74th Cong. (1935), reprinted in 2 Legislative History of THE NATIONAL LABOR Relations ACt 1935, at 2302 (2d ed. 1986). See also Statement of Senator Wagner, reprinted in 1 Legislative History of the NATIONAL LABOR RElATIONS ACT 1935, at 15 (2d ed. 1986) ("Employers are allowed to unite in trade associations in order to pool their information and experience . . . But it is fraught with great danger to workers and consumers if it is not counterbalanced by the equal organization and equal bargaining power of employees . . . It is necessary to insure a wise distribution of wealth between management and labor."). 


\section{Constitutional Arguments}

The First and Thirteenth Amendments of the U.S. Constitution support a labor organizing privilege as well. The Thirteenth Amendment ${ }^{231}$ is traditionally interpreted narrowly, encompassing only the right to quit and not a broader range of labor rights. ${ }^{232}$ However, according to Lea Vandervelde, the legislative history of the Amendment suggests that many members of Congress considered it to be "a charter for labor freedom," and not just a narrow ban on slavery and involuntary servitude. ${ }^{233}$ The floor debates, while focused primarily on securing racial equality, also 'reflect[ed] a desire to improve all workers' status by recognizing the dignity of labor, guaranteeing workers a wide range of opportunities for advancement, and raising the floor of legal rights accorded all working men." 234

The nexus of the Thirteenth Amendment and freedom of association guaranteed by the First Amendment provides an even stronger constitutional basis for the right to organize, strike, and collectively bargain. ${ }^{235}$ As James Grey Pope explains:

$[\mathrm{W}]$ ithout the freedom of association, workers would be in a condition of involuntary servitude in violation of the Thirteenth Amendment. According to the Supreme Court, the purpose of the amendment was "to make labor free by prohibiting that control by which the personal service of one man is disposed of or coerced for another's benefit." But, as recognized by both Congress and the Supreme Court, "the individual unorganized worker is commonly helpless to exercise actual liberty of contract and to protect his freedom of labor, and thereby to obtain acceptable terms and conditions of employment." Only by exercising the freedom of association could workers deal with corporate employers on a basis of equality. ${ }^{236}$

231. U.S. CONST. amend. XIII, $\S 1$ ("Neither slavery nor involuntary servitude, except as a punishment for crime whereof the party shall have been duly convicted, shall exist within the United States, or any place subject to their jurisdiction.").

232. See, e.g., Pollock v. Williams, 322 U.S. 4, 18 (1944) (“[T] he defense against oppressive hours, pay, working conditions, or treatment is the right to change employers.").

233. Lea S. Vandervelde, The Labor Vision of the Thirteenth Amendment, 138 U. PA. L. REV. 437, 438 (1989).

234. Id. at 448. See also Michael Scimone, More to Lose Than Your Chains: Realizing the Ideals of the Thirteenth Amendment, 12 N.Y. CITY L. REV. 175, 181 (2008) ("In the case of the Thirteenth Amendment, there is evidence that the original understanding was far more expansive and radical than the modern one.").

235. James Gray Pope, The First Amendment, the Thirteenth Amendment, and the Right to Organize in the Twenty-First Century, 51 RuTGERS L. REV. 941, 961-70 (1999).

236. Jim Pope, Next Wave Organizing and the Shift to a New Paradigm of Labor Law, 50 N.Y.L. SCH. L. REV. 515, 549 (2006) (internal citations and footnotes omitted). 
Although Pope resurrected the Thirteenth Amendment as a vehicle for securing labor rights, the idea actually predates the NLRA by many decades. Labor activists of the early twentieth century believed that the rights to organize, strike, and collectively bargain were fundamental rights protected by the U.S. Constitution. ${ }^{237}$ That idea had gained some traction in the courts, with several courts upholding the right to strike on Thirteenth Amendment grounds. ${ }^{238}$ When enacting the NLRA, however, Congress made the decision to rely on the Commerce Clause and not the Thirteenth Amendment, ${ }^{239}$ despite the push from labor leaders for a rights-based justification. ${ }^{240}$ This was a strategic choice on the part of the NLRA's drafters, not a rejection of the rights-based understanding of the Thirteenth Amendment. ${ }^{241}$ Nevertheless, it was a missed opportunity to confirm the original understanding of the Amendment.

Since then, constitutional arguments have been subordinated to section 7's broad statutory language. But courts could revive the constitutional foundation of labor rights in recognizing a labor organizing privilege. The Supreme Court has never squarely addressed whether the Thirteenth Amendment protects a broad right to organize, but the right-to-strike cases of the 1940s imply that there is special protection under the First Amendment when labor rights are implicated. ${ }^{242}$ In affirming the right to strike, the Court held in Thornhill $v$. Alabama that "[f]ree discussion concerning the conditions in industry and the causes of labor disputes appears to us indispensable to the effective and intelligent use of the processes of popular government to shape the destiny of modern industrial society." 243 In later cases, the Court concluded that the ban on secondary boycotts did not violate the First Amendment, but did so while reaffirming the important First Amendment values at stake in labor disputes. ${ }^{244}$

237. James Gray Pope, Labor's Constitution of Freedom, 106 YALE L.J. 941,942 (1997).

238. See Pope, supra note 235, at 965 n.99.

239. See 29 U.S.C. $\S 151$ (2012) ("Experience has proved that protection by law of the right of employees to organize and bargain collectively safeguards commerce from injury, impairment, or interruption, and promotes the flow of commerce by removing certain recognized sources of industrial strife and unrest.").

240. James Gray Pope, The Thirteenth Amendment Versus the Commerce Clause: Labor and the Shaping of American Constitutional Law, 1921-1957, 102 Colum. L. REV. 1, 7 (2002).

241. Id.

242. See Pope, supra note 235, at 965-66.

243. 310 U.S. 88, 103 (1940). See also Am. Fed'n of Labor v. Swing, 312 U.S. 321 (1941) ("A state cannot exclude workingmen from peacefully exercising the right of free communication by drawing the circle of economic competition between employers and workers so small as to contain only an employer and those directly employed by him. The interdependence of economic interest of all engaged in the same industry has become a commonplace.").

244. NLRB v. Fruit \& Vegetable Packers \& Warehousemen, Local 760, 377 U.S. 58, 63 (1964) (expressing "concern that a broad ban against peaceful picketing might collide with the guarantees of the First Amendment"). Many scholars have argued that the bans on mass picketing and secondary boycotts violate the First Amendment because they constitute viewpoint discrimination against labor speech. See Joseph L. Guza, A Cure for Laryngitis: A First Amendment Challenge to the NLRA's Ban on Secondary Picketing, 59 BuFF. L. REV. 1267, 1280 (2011) (noting the tension between First Amendment protection and ban on secondary picketing in 
As Pope has observed, First Amendment rights tend to be at their zenith when they intersect with other constitutionally protected rights. ${ }^{245}$ In several cases, for instance, the Supreme Court has suggested that "speech to protest racial discrimination" 246 and religious speech ${ }^{247}$ deserve heightened protection under the First Amendment. Although the Court has never articulated a theory as to which speech deserves heightened protection, Charlotte Garden has effectively argued that a theory of First Amendment jurisprudence based on deliberative democracy would support heightened protection for labor speech as well. $^{248}$ On this theory, labor unions and others engaged in labor speech contribute to civil society through the discourse they generate, and therefore are deserving of special protection. ${ }^{249}$ A return to the original understanding of the Thirteenth Amendment permits one to take this argument a step further beyond labor speech, to encompass a broader range of labor rights such as the rights to organize and collectively bargain.

If labor rights are constitutionally protected, then a constitutional labor organizing privilege is required. Indeed, the Supreme Court has several times recognized evidentiary privileges in order to protect First Amendment rights. One such evidentiary privilege is the reporter-source privilege, which the Supreme Court considered in Branzburg v. Hayes. ${ }^{250}$ Lower courts have come to different conclusions about whether Branzburg, which contained four separate opinions and no clear majority, created a reporter-source privilege, ${ }^{251}$ but most lower courts have found that a qualified privilege exists. ${ }^{252}$ Over thirty states have legislatively adopted a reporter-source privilege. ${ }^{253}$

Court's jurisprudence); Pope, supra note 235, at 950; Ian Hayes, The Unconstitutionality of Section 8(b)(4)(II)(b) and the Supreme Court's Unique Treatment of Union Speech, 28 ABA J. LAB. \& EMP. L. 129, 130 (2012); Dan Ganin, A Mock Funeral for a First Amendment Double Standard: Containing Coercion in Secondary Labor Boycotts, 92 MinN. L. REv. 1539, 1572 (2008).

245. Pope, supra note 236, at 966.

246. NAACP v. Claiborne Hardware Co., 458 U.S. 886, 915 (1982) (citing Henry v. First Nat'l Bank of Clarksdale, 595 F.2d 291, 303 (1979)); Garner v. Louisiana, 368 U.S. 157, 200 (1961) (Harlan, J., concurring).

247. Watchtower Bible \& Tract Soc'y of New York, Inc. v. Vill. of Stratton, 536 U.S. 150, 160 (2002).

248. Charlotte Garden, Labor Values Are First Amendment Values: Why Union Comprehensive Campaigns Are Protected Speech, 79 FordHAm L. ReV. 2617, 2650 (2011).

249. Id.

250. Branzburg v. Hayes, 408 U.S. 665, 690 (1972).

251. See N.Y. Times Co. v. Gonzales, 382 F. Supp. 2d 457, 486 (S.D.N.Y. 2005) (discussing how different courts have interpreted Branzburg), vacated and remanded, 459 F.3d 160 (2d Cir. 2006).

252. See Ashcraft v. Conoco, Inc., 218 F.3d 282, 287 (4th Cir. 2000); Gonzales v. National Broadcasting Co., Inc., 194 F.3d 29, 36-37 (2d Cir. 1999); United States v. LaRouche Campaign, 841 F.2d 1176, 1181 (1st Cir. 1988). But see In re Grand Jury Subpoena, Judith Miller, 438 F.3d 1141, 1148 (D.C. Cir. 2006).

253. Ala. Code $\S 12-21-142$ (2014); Ariz. Rev. Stat. Ann. § 12-2237 (2014); Ark. Code AnN. § 16-85-510 (West 2011); CAL. Evid. Code $§ 1070$ (West 2014); Colo. Rev. Stat. AnN. $\S \S 13-90-119,24-72.5-101$ (West 2014); ConN. Gen. STAT. $§ 52-146 t$ (2015); Del. Code AnN. tit. $10, \S \S 4320-4326$ (West 2015); D.C. Code AnN. § 16-4702 (2001); Fla. Stat. AnN. § 90.5015 
Courts that have recognized a reporter-source privilege have done so on the grounds that the freedom of the press guaranteed by the First Amendment requires that reporters be able to communicate confidentially with their sources. "If reporters were routinely required to divulge the identities of their sources, the free flow of newsworthy information would be restrained and the public's understanding of important issues and events would be hampered in ways inconsistent with a healthy republic." ${ }^{254}$ This argument is essentially a practical one-freedom of the press becomes illusory if journalists cannot protect their sources from disclosure. Similar logic can be applied to a labor organizing privilege. If the privilege is necessary to secure the rights to organize and collectively bargain, which are themselves constitutionally protected, then it might be justified on constitutional grounds.

Evidentiary privileges to protect the First Amendment's freedom of association are grounded in Supreme Court precedent. In NAACP v. Alabama ex rel. Patterson, the Supreme Court held that requiring the NAACP to disclose its membership list during the course of litigation violated its members' right to freedom of association as guaranteed by the First and Fourteenth Amendments, stressing the "vital relationship between freedom to associate and privacy in one's associations." 255 One federal court has already extended the reasoning in NAACP v. Alabama to the union membership context. ${ }^{256}$ The court in International Union v. Garner emphasized that allowing discovery into union members' identities "would further chill and infringe rights to association and is geared substantially to inhibiting the organizational efforts of plaintiffs." 257 Although the privilege sought in Garner was narrower than the broad labor organizing privilege proposed in this article, the same reasoning would support a broader privilege as well.

(West 2014); Ga. Code AnN. § 24-9-30 (West 2013); 735 Ill. Comp. Stat. AnN. 5/8-901 (West 2014); Ind. Code AnN. § 34-46-4-1-2 (West 2015); Iowa Code AnN. § 622.10; Ky. Rev. Stat. AnN. § 421.100 (West 2014); LA. Rev. StAT. AnN. §§ 45:1451-:1459 (West 2014); Md. Code AnN., CTS. \& Jud. Proc. § 9-112 (West 2014); Mich. Comp. Laws AnN. § 767.5a (West 2015); Minn. Stat. AnN. §§ 595.021-.025 (West 2015); Mont. Code AnN. §§ 26-1-901 to -903 (2014); Neb. Rev. Stat. §§ 20-144 to -147 (2015); Nev. Rev. Stat. § 49.275 (2013); N.J. Stat. AnN. §2A:84A-21 (West 2015); N.M. R. EvID. 11-514; N.Y. CiV. RighTS LAW §79-h (McKinney 2015); N.C. Gen. Stat. § 8-53.11 (2014); Ohio Rev. Code AnN. §§ 2739.04, 2739.12, 2921.22(G)(3) (West 2014); OKLa. Stat. AnN. tit. 12, §2506 (West 2014); OR. Rev. STAT. §§ 44.510-.540 (2014); 42 Pa. Cons. Stat. AnN. § 5942 (West 2014); R.I. Gen. LaWs § 9-19.1-3 (2014); S.C. CODE ANN. § 19-11-100 (2014); TENN. CODE ANN. § 24-1-208 (West 2014).

254. See Conoco, 218 F.3d at 287.

255. 357 U.S. 449, 462 (1958).

256. Int'l Union v. Garner, 102 F.R.D. 109 (M.D. Tenn. 1984).

257. Id. at 115. Other courts have sought to avoid reaching the question. See Am. Airlines, Inc. v. Superior Court, 8 Cal. Rptr. 3d 146, 151 (2003) (finding associational rights not implicated because union members' identities were already public); Patterson v. Heartland Indus. Partners, LLP, 225 F.R.D. 204, 206 (N.D. Ohio 2004) (declining to reach issue after parties agreed to redact names of union members). 
A constitutional privilege has several advantages over a common law privilege. Perhaps most importantly, a constitutional privilege could apply to workers and labor representatives who do not meet the definitions of "employee" and "labor organization" in the NLRA, which might limit a common law privilege. It could be extended to protect agricultural and domestic workers, for instance, as well as "independent contractors." It could also cover communications between workers and non-traditional labor organizations such as worker centers. Moreover, a constitutional privilege would be protected from anti-union politics in state legislatures and Congress.

Even if courts find that a labor organizing privilege is not required by the First and Thirteenth Amendments, these constitutional protections could inform courts' and legislatures' decisions to adopt a common law privilege. In this way, a labor organizing privilege would be like the marital communications and the clergy-congregant privileges, which are often justified by reference to the Supreme Court's privacy jurisprudence and the Free Exercise Clause of the First Amendment, respectively. ${ }^{258}$ Whether the relationship between workers should be "sedulously fostered" under the instrumental justification or given special protection under the humanitarian justification should be informed by a reading of the Constitution that protects that relationship. ${ }^{259}$

\section{E. Existing Labor-related Evidentiary Privileges}

Although a labor organizing privilege as envisioned in this article is novel, there are several other labor-related evidentiary privileges that have paved the way. When deciding to recognize the privilege, courts could frame a labor organizing privilege as an expansion of the "union representative privilege." Likewise, courts could draw from the experiences of the NLRB, which has already recognized the importance of evidentiary privileges to protect workers' labor rights.

\section{Union Representative Privilege}

Several state courts ${ }^{260}$ and one state legislature ${ }^{261}$ have recognized a more limited form of a labor organizing privilege, applying to confidential

258. See Dudley, supra note 164, at 1818.

259. Imwinkelried has argued that courts developing a humanistic justification for evidentiary privileges should look to established constitutional principles not because the Constitution requires certain privileges, but because the same concepts of privacy and autonomy have already been considered at depth in the constitutional context and are helpful in shaping the humanitarian analysis. See THE New Wigmore, supra note 149, at $\S$ 5.3.1.

260. See, e.g., City of Newburgh v. Newman, 421 N.Y.S.2d 673 (App. Div. 1979); Seelig v. Shepherd, 578 N.Y.S.2d 965 (Sup. Ct. 1991); Peterson v. State, 280 P.3d 559 (Alaska 2012); Int'l Bhd. of Elec. Workers v. Pub. Util. Dist. 1, Dec. 7656-A, 2003 WA PERC LEXIS 46, 55 (Wash. Pub. Employment Relations Comm'n., June 11, 2003); N.H. Troopers Ass'n v. N.H. Dept. of Safety, Dec. $94-74$ (N.H. Pub. Employee Relations Bd., Aug. 31, 1994).

261. 735 Ill. COMP. StAT. 5/8-803.5 (2005). 
communications between a union representative and a union member in the context of disciplinary proceedings. This "union representative privilege" is similar to other professional privileges such as the attorney-client privilege and is often justified on similar grounds. ${ }^{262}$ For instance, in City of Newburgh v. Newman, the New York Appellate Division reasoned that "[q]uestioning of a union official as to his observations and communications with a union member facing disciplinary proceedings, if permitted, would tend to deter members of the union from seeking advice and representation with regard to pending charges, thereby seriously impeding their participation in an employee organization."263 Because it has been analogized to and seen as an extension of the attorney-client privilege, it has only limited utility for making the argument for a broader privilege. Nevertheless, it represents the closest courts have come to recognizing a labor organizing privilege of any sort, and therefore is relevant to the discussion here.

While some scholars have argued that a union representative privilege is "emerging" "264 and one treatise has included it in its list of "privileges with substantial authority for recognition,"265 Michael Moberly's article on the privilege aptly demonstrates that it is far from well-established. ${ }^{266}$ Most federal courts to have considered a union representative privilege have rejected it. ${ }^{267}$ The one federal court to recognize the privilege did so in Illinois, ${ }^{268}$ which also is the only state to have legislatively recognized the privilege. Given federal courts' reluctance to recognize privileges that do not exist under state law, ${ }^{269}$ this is unsurprising. Neither have all state courts to consider the question decided to recognize the privilege. ${ }^{270}$ In American Airlines, Inc. v. Superior Court, for instance, a California appellate court held that a union representative privilege was neither constitutionally nor statutorily required under California law, despite the fiduciary duty of union representatives towards union members. ${ }^{271}$ And in

262. Moberly, supra note 28 , at $555 \mathrm{n} .374$ (comparing union representative privilege to the "analogous attorney-client privilege").

263. 421 N.Y.S.2d at $675-76$.

264. See Rubinstein, supra note 28, at 232.

265. Federal Testimonial Privileges $2 \mathrm{~d} \S 10: 7$.

266. Moberly, supra note 28, at 534-35.

267. In re Grand Jury Subpoenas Dated January 20, 1998, 995 F. Supp. 332 (E.D.N.Y. 1998); U.S. Dep't of Justice v. Fed. Labor Relations Auth., 39 F.3d 361 (D.C. Cir. 1994); Walker v. Huie, 142 F.R.D. 497, 501 (D. Utah 1992).

268. Bell v. Village of Streamwood, 806 F. Supp. 2d 1052 (N.D. Ill. 2011).

269. Jaffee v. Redmond, 518 U.S. 1, 12 (1996) ("We have previously observed that the policy decisions of the States bear on the question whether federal courts should recognize a new privilege or amend the coverage of an existing one.").

270. See, e.g., Hunt v. Maricopa Cnty. Emp. Merit Sys. Comm'n, 127 Ariz. 259, 264 (1980).

271. See Am. Airlines, Inc. v. State, 8 Cal. Rptr. 3d 146, 151 (2003). There is a legislative push in California to overturn American Airlines by enacting a statutory union representative privilege. See A.B. 729, 2013-2014 Sess. (Cal. 2013) ("This bill would provide that a union agent, as defined, and a represented employee or represented former employee have a privilege to refuse 
New York, the legislature was unable to codify the decision in City of Newburgh and extend it to non-public union members because of a gubernatorial veto. ${ }^{272}$

While the union representative privilege, where it exists, provides important protections to union members, it suffers from a number of limitations. First, the privilege often has been held to apply only to communications concerning disciplinary proceedings, leaving unprivileged a large swath of communications that would be protected under a broader privilege. ${ }^{273}$ Second, every court to recognize the privilege has done so in the union context. No court has recognized the privilege for communications between workers or between a worker and a non-union organizer or representative. Still, the union representative privilege shows that courts and legislatures have, on occasion, extended an evidentiary privilege that protects workers in labor disputes.

\section{NLRB Privileges}

The NLRB has established a number of evidentiary privileges that apply in Board administrative proceedings designed to protect the right to organize and collectively bargain. For instance, in NLRB v. Robbins Tire, the Supreme Court affirmed an NLRB rule that the Board's investigatory materials, including witness statements, can be protected from disclosure during unfair labor practice proceedings because of the risk of intimidation and harassment:

The danger of witness intimidation is particularly acute with respect to current employees-whether rank and file, supervisory, or managerial-over whom the employer, by virtue of the employment relationship, may exercise intense leverage. Not only can the employer fire the employee, but job assignments can be switched, hours can be adjusted, wage and salary increases held up, and other more subtle forms of influence exerted. A union can often exercise similar authority over its members and officers. As the lower courts have recognized, due to the peculiar character of labor litigation, the witnesses are especially likely to be inhibited by fear of the employer's or-in some cases - the union's capacity for reprisal and harassment. ${ }^{274}$

to disclose any confidential communication between the employee or former employee and the union agent while the union agent was acting in his or her representative capacity ....").

272. In re Grand Jury Subpoenas, 995 F. Supp. 332, 336 (E.D.N.Y. 1998).

273. See, e.g., City of Newburgh v. Newman, 421 N.Y.S.2d 673, 676 (App. Div. 1979) ("Any privilege established by the decision of the board is strictly limited to communications between a union member and an officer of the union, and operates only as against the public employer, on a matter where the member has a right to be represented by a union representative, and then only where the observations and communications are made in the performance of a union duty.").

274. NLRB v. Robbins Tire, 437 U.S. 214, 240 (1978) (internal citations and quotations omitted). See also Harvey's Wagon Wheel v. NLRB, 550 F.2d 1139, (9th Cir. 1977); H.B. Zachry 
The NLRB has also quashed subpoenas calling for the disclosure of confidential communications between workers. ${ }^{275}$ The NLRB affirmed Berbiglia, Inc., in which an administrative law judge reasoned that "requiring the Union to open its files to Respondent would be inconsistent with and subversive of the very essence of collective bargaining and the quasi-fiduciary relationship between a union and its members." 276 Finally, in National Telephone Directory Corp., the NLRB and Fifth Circuit affirmed that the attendance lists from union meetings and union membership lists are privileged in NLRB proceedings. ${ }^{277}$ The Federal Labor Relations Authority ("FLRA"), the agency that enforces labor rights of federal employees, has recognized a similar evidentiary privilege in its administrative proceedings. ${ }^{278}$

The NLRB is not bound by the Federal Rules of Evidence and has broad discretion to craft evidentiary rules of its own. ${ }^{279}$ But given the depth of its experience adjudicating labor disputes, the decisions the NLRB has made with respect to privileges are instructive. Given that courts may be willing to afford some deference to the NLRB and its expertise, and given that the NLRB privileges themselves are more similar to the one envisioned in this article, advocates arguing for a labor organizing privilege should consider framing their efforts as an expansion of the NLRB privileges, rather than as an expansion of the union representative privilege.

IV.

\section{DEFINING THE PRIVILEGE}

Thus far, this article has argued that a labor organizing privilege is both good policy and consistent with existing privilege law, but there remain several questions regarding the scope of the privilege. First, though definitions of

Co., 310 N.L.R.B. 1037 (1993). The Robbins Tire case was brought under the Freedom of Information Act ("FOIA") with the NLRB arguing that the documents sought-including witness statements-were protected from disclosure under Exemption 7, which protects "records or information compiled for law enforcement purposes" if disclosure "could reasonably be expected to interfere with enforcement proceedings.” See 5 U.S.C. § 552(b)(7) (2012). The Supreme Court found that disclosure would interfere with the NLRB proceedings because of the chilling effect it would have on workers. While Robbins Tire has little legal applicability outside of the FOIA context, the Supreme Court's reasoning could apply with equal force to the effects of disclosure during discovery in federal court proceedings.

275. Berbiglia, Inc., 233 N.L.R.B. 1476, 1495 (1977); Champ, Corp., 291 N.L.R.B. 803, 817 (1988), enforced, 933 F.2d 688 (9th Cir. 1990); Morton, Int'l, 1993 N.L.R.B. Lexis 1098 (ALJ 1993). But see Taylor Lumber \& Treating, Inc., 326 N.L.R.B. 1298, 1300 (1998) (finding no privilege for communications concerning management bargaining strategy).

276. Berbiglia, 233 N.L.R.B. at 1495.

277. Nat'l Tele. Directory Corp., 319 N.L.R.B. 420 (1995); N. States Beef, 311 N.L.R.B. 1056, 1057 (1993); Pac. Molasses Co. v. NLRB, 577 F.2d 1172 (5th Cir. 1978).

278. U.S. Dep't of Treasury Customs Serv., Wash., D.C., 38 F.L.R.A. 1300 (1991). The D.C. Circuit upheld a limited FLRA privilege in U.S. Dep't of Justice v. Fed. Labor Relations Auth., 39 F.3d 361, 369 (D.C. Cir. 1994).

279. See Robbins Tire, 437 U.S. at 236-37 n.16. 
"worker" and "representative" may vary by jurisdiction, these terms should be construed broadly and with an eye towards inclusion of workers who do not otherwise have the protections of traditional labor law. ${ }^{280}$ For instance, a model statute enacting a labor organizing privilege could be as follows:

(A) A worker has the privilege to refuse to disclose, or prevent others from disclosing, confidential communications concerning organizing and collective bargaining between the worker and another worker or the worker's representative.

(B) This section uses the following definitions: (1) "Worker" in this section means any person who engages in work for another person or corporate entity for remuneration; (2) "Representative" in this section means any person designated by a worker to represent the worker in matters related to organizing and collective bargaining; (3) "Organizing" in this section means workers' concerted activities for the purpose of mutual aid or protection; (4) "Collective bargaining" in this section means the collective negotiation of pay and other working conditions.

Although this article has at times used the term "organizer," the term "representative" more accurately describes the relationship the privilege seeks to protect. An organizer may very well be a worker's representative, but there are also situations in which he or she is not. ${ }^{281}$ Without the relationship established between a worker and his or her representative, there is no claim to privilege. ${ }^{282}$

There are several outstanding questions to be addressed at the outset, including whether the privilege should be qualified or absolute, whether it should apply in criminal proceedings, and whether it should apply to an employer's confidential communications.

\section{A. Absolute vs. Qualified Privilege}

The answer to the question of whether a labor organizing privilege should be absolute or qualified depends in large part on which justification is used to support the privilege. A Wigmorean privilege would most likely be absolute, ${ }^{283}$ while a privilege justified on humanistic, egalitarian, or constitutional grounds

280. These "excluded workers" include farm workers, domestic workers, and independent contractors. 29 U.S.C. $§ 152$ (3) (2012).

281. A labor organizing privilege would not prevent an anti-union worker to testify about conversations with an organizer, for example.

282. Even if such an organizer were considered a "representative," the anti-union worker could waive the privilege. Furthermore, communications would not have been made in confidence.

283. 1 MCCORMICK, supra note 145 , at $\S 77$. 
would probably be qualified. ${ }^{284}$ Each has advantages and disadvantages from a policy perspective.

A qualified privilege would minimize the potential harm to the integrity of the judicial process by allowing courts to weigh the interests of the parties when deciding whether to recognize the privilege in individual cases. In particular, courts could consider whether the employer has an improper motive, whether the evidence is relevant, and whether there are less intrusive ways to obtain the evidence. ${ }^{285}$ This would allow courts to prevent most abusive employer practices without sacrificing the judiciary's ability to consider most relevant evidence in adjudicating claims. Moreover, courts may be more likely to adopt new evidentiary privileges if they are qualified. ${ }^{286}$ Perhaps the best reason to advocate for a qualified privilege is that a qualified privilege is better than no privilege at all. ${ }^{287}$

But there are advantages to an absolute privilege as well, chiefly the clarity and security that workers enjoy in knowing their communications will remain confidential in all circumstances. ${ }^{288}$ Furthermore, like the NLRB's balancing test for determining whether to enjoin abusive discovery tactics or the Supreme Court's decision in Bill Johnson's Restaurants, a qualified privilege would be

284. Imwinkelried, supra note 154, at 340. The reporter-source and associational First Amendment privileges have both been recognized as qualified privileges. See Gonzales v. Nat'1 Broad. Co., Inc., 194 F.3d 29, 32, 35 n.6 (2d Cir. 1999) ("This circuit has long recognized the existence of a qualified privilege for journalistic information."); NAACP v. Alabama, 357 U.S. 449, 463-66 (1958) (weighing the interest of the NAACP's members against the interests of the State of Alabama). Thus, any labor organizing privilege recognized on constitutional grounds would likely be qualified as well.

285. Int'l Union v. Garner, 102 F.R.D. 108, 116 (M.D. Tenn. 1984) (examining the employer's motive, the relevance of the evidence to the litigation, and whether the employer could obtain the evidence in less intrusive ways in deciding whether to apply a qualified privilege).

286. See Imwinkelried, supra note 154, at 337.

287. An alternative to a labor organizing privilege would be for courts to grant protective orders under Fed. R. Civ. P. 26(c) on the grounds that discovery into workers' confidential communications causes "annoyance, embarrassment, oppression, or undue burden or expense." Courts have taken precisely this route with respect to the discovery of immigration status in wageand-hour cases, finding that "[i]f forced to disclose their immigration status, most undocumented aliens would withdraw their claims or refrain from bringing an action . . . in the first instance. This would effectively eliminate the FLSA as a means for protecting undocumented workers from exploitation and retaliation.” Flores v. Amigon, 233 F. Supp. 2d 462, 465 n.2 (E.D.N.Y. 2002). See also Galaviz-Zamora v. Brady Farms, Inc., 230 F.R.D. 499, 502 (W.D. Mich. 2005); Villareal v. El Chile, Inc., 266 F.R.D. 207, 214 (N.D. Ill. 2010). The same "in terrorem effect" that courts have identified in the context of immigration status is also applicable to the labor organizing context and could form the basis for a protective order on similar grounds. In fact, a protective order in the organizing context is on even stronger footing because the workers' communications are statutorily and constitutionally protected, unlike information regarding undocumented status. It would, however, require workers to affirmatively seek protection from the court, unlike an evidentiary privilege, which could be invoked by the worker in the first instance. It would also allow employers to make arguments based on the relevance of the evidence sought, which would increase uncertainty for workers about whether their communications will be protected, and would allow employers to use artful pleadings to avoid a protective order.

288. See Imwinkelried, supra note 150, at 148. 
open to employer manipulation and abuse. At the very least, a qualified privilege would encourage protracted litigation over whether the privilege should be recognized in a particular case and could potentially drive up litigation costs. ${ }^{289}$ Given that driving up litigation costs is often a motivating factor in an employer's decision to utilize abusive litigation tactics, a qualified privilege may not actually protect workers.

\section{B. Scope of the Privilege}

Rather than a qualified privilege, a better compromise may be the creation of a narrower absolute privilege. For instance, courts could recognize an absolute privilege limited to civil cases, on the grounds that the public interest in obtaining a just result is at its zenith in criminal cases, ${ }^{290}$ while the policy arguments in favor of a labor organizing privilege may be at their weakest when alleged criminal activity has occurred. Employer retaliation, one of the principle reasons to support a labor organizing privilege, is less likely to be a factor in a criminal prosecution. Indeed, several courts, while not deciding the issue of whether a labor organizing privilege exists in general, have refused to recognize the privilege in cases in which the employer is not a party, finding no policy reason to do so. ${ }^{291}$ Although evidentiary privileges traditionally apply in all proceedings, the reluctance of these courts to extend the privilege in cases in which the employer is not a party suggests that some limitation may be appropriate and, in fact, necessary to gain widespread judicial acceptance. ${ }^{292}$

Courts could also recognize a crime-fraud exception to a labor organizing privilege, similar to the corresponding exception to the attorney-client privilege, which states that "[a] client who has sought assistance for the purpose of committing a crime or fraud (others add: 'or tort') cannot require secrecy. The privilege ends when the client seeks to involve the attorney in wrongdoing." 293 Communications that amount to a criminal conspiracy, or an attempted criminal conspiracy, could be excluded from communications protected by the labor organizing privilege. This would not entirely ameliorate the concerns some may have about a privilege that protects communications between labor organizations

289. See Randall D. Eliason, The Problems with the Reporter's Privilege, 57 AM. U. L. REV. 1341, 1378 (2008) (discussing how a qualified reporter-source privilege will have the result of driving up litigation costs).

290. See United States v. Nixon, 418 U.S. 683, 711 (1974) ("The right to the production of all evidence at a criminal trial . . has constitutional dimensions.").

291. In re Grand Jury Subpoenas, 995 F. Supp 332, 336 (E.D.N.Y. 1998) (finding that a labor organizing privilege "has not . . . been held to apply against any party other than the employer"); U.S. Dep't of Justice v. Fed. Labor Relations Auth., 39 F.3d 361, 369 (D.C. Cir. 1994) (holding that the union representative privilege with respect to disclosures to management did not extend to disclosures to neutral government bodies).

292. But see Rubinstein, supra note 28 , at 223 (advocating for a "labor relations" privilege that applies in all contexts, not just in employer-employee disputes).

293. David J. Fried, Too High a Price for Truth: The Exception to the Attorney-Client Privilege for Contemplated Crimes and Frauds, 64 N.C. L. REV. 443, 443-44 (1986). 
and workers, but could at least minimize the impact of such a privilege in cases where illegal behavior by unions becomes an issue.

The problem with recognizing a crime-fraud exception is the risk that the exception would swallow the rule as employers strain to portray a broad range of union conduct as "criminal." But certain checks can be put into place to prevent this type of abuse. In the attorney-client context, for instance, the party seeking disclosure must make a prima facie showing that a crime has occurred. ${ }^{294}$ The burden of proof required to make a prima facie case varies by jurisdiction, but can be as high as a preponderance of the evidence. ${ }^{295}$ Although this showing would not prevent all abuse, it would at least provide some protection to workers and organizers accused of criminal conduct.

\section{Bilateral Privilege}

Some scholars, in considering a union representative privilege, have assumed that such a privilege - and by extension a broader labor organizing privilege - would be bilateral. ${ }^{296}$ In other words, employers would also be able to take advantage of the privilege to keep confidential their communications concerning labor organizing and collective bargaining. To some extent, this logic is appealing. Why should one side of a negotiation enjoy a privilege that the other side does not? But this conclusion assumes that workers and employers are similarly situated, which they are not. For one thing, most employers now hire outside consultants, typically attorneys, to seek legal advice when they become aware of an organizing campaign. ${ }^{297}$ Thus, many of the employer communications that would be covered under a bilateral privilege are already protected by attorney-client privilege. ${ }^{298}$

Second, and perhaps most importantly, there are sound policy reasons to recognize a privilege for workers and not for employers. As discussed above, the NLRA sought to rebalance power between employers and workers, ${ }^{299}$ and a unilateral privilege would be consistent with this policy. The equities that counsel in favor of a labor organizing privilege for workers - including the rise of abusive litigation tactics by employers designed to retaliate against and harass

294. Clark v. United States, 289 U.S. 1, 15 (1933).

295. See, e.g., Purcell v. D.A. for Suffolk Dist., 676 N.E.2d 436, 439 (Mass. 1997).

296. See, e.g., Rubinstein, supra note 28 , at 223 n.4.

297. BRONFENBRENNER, supra note 13, at 23 (stating that seventy-five percent of employers in NLRB contested elections hired outside management consultants); Andrew J. Kahn, Problems of Professional Ethics in Labor Law, 1987 DET. C.L. REV. 731, 733 (1987) (noting the rise in use of attorneys as labor management consultants); The Liability of Labor Relations Consultants for Advising Unfair Labor Practices, 97 HARv. L. REv. 529, 529 n.4 (1983) (noting that eighty-seven percent of management consultants are lawyers).

298. The Liability of Labor Relations Consultants, 97 HARV. L. REV. at 543 ("Because a lawyer, in counseling supervisors, gives legal advice about what can and cannot be done, the privilege almost always applies during organizing campaigns." (internal citations omitted)).

299. See supra Part III.B.2. 
workers $^{300}$ — simply do not exist for employers. In fact, a privilege that would protect an employer from disclosing unfair labor practices would likely subvert the policy objectives of the NLRA by making it even harder for workers to remedy unlawful behavior by employers.

Finally, many of the justifications that support a labor organizing privilege do not support a bilateral privilege. Specifically, the humanistic, egalitarian, and constitutional grounds for recognizing a labor organizing privilege would not apply in equal measure to an employer privilege. The Thirteenth Amendment does not contain an equivalent right for employers. Nor would a privilege be justified on egalitarian grounds, since it is undisputed that employers already enjoy a strategic and resource advantage in organizing campaigns and collective bargaining.

The humanistic justification comes closest to providing a basis for an employer privilege. Perhaps one could argue that employers need decisional autonomy when dealing with their employees. But corporations do not enjoy the same privacy rights as individuals do. ${ }^{301}$ Although individual members of management may have the right to decisional privacy and autonomy, it is not their individual interest, but the interests of the corporation, that an employer privilege would protect. While a bilateral privilege may be more politically feasible, there is no clear policy reason to advocate for a labor organizing privilege that would protect employers as well as workers.

In sum, the best privilege for workers would be an absolute unilateral privilege that applies in both civil and criminal proceedings. However, the political feasibility of a broad privilege may require advocates to accept some tradeoffs. Limiting the privilege to civil proceedings is one possible tradeoff that is likely to have the least impact on the effectiveness of the privilege.

\section{CONCLUSION}

In September 2012, the Restaurant Opportunity Center of New York ("ROC-NY") and B\&B Hospitality Group, owned by celebrity chef Mario Batali, announced that they had settled the claims of thirty-one workers at Batali's upscale New York restaurant, Del Posto, for $\$ 1.15$ million. ${ }^{302}$ What did not make the papers is that the settlement also provided for the dismissal of a suit that B\&B Hospitality Group had brought against ROC-NY and several of its staff and board members. That suit, which alleged that ROC-NY had defamed Mr. Batali during the course of protests outside the restaurant, among other

300. See supra Part I.

301. See FCC v. AT\&T Inc., 131 S. Ct. 1177, 1181 (2011) (finding that corporations do not have privacy rights under the Freedom of Information Act); Fleck \& Assocs. v. City of Phoenix, 471 F.3d 1100, 1104 (9th Cir. 2006) (finding no constitutional corporate right of privacy).

302. Sumathi Reddy, Batali Settles Case with Restaurant Workers Group, WALl St. J., (Sept. 24, 2012), http://blogs.wsj.com/metropolis/2012/09/24/batali-settles-case-with-restaurant-workers -group. 
claims, had been grinding through New York state courts for more than a year. ${ }^{303}$ The state court judge had temporarily granted an injunction barring ROC-NY from picketing outside the restaurant ${ }^{304}$ and denied a motion to dismiss under New York's anti-SLAPP statutes on a technicality. ${ }^{305}$ B\&B Hospitality Group had begun discovery into ROC-NY's organizing strategy and its communications with the workers involved in the case. ${ }^{306}$

The organizing campaign in that case did not fall apart. The employer's strategy - to intimidate the workers into dropping their suit, to inflict costs that would stymie ROC-NY's organizing efforts, and to use the discovery process to gain valuable information it could use against ROC-NY-ultimately failed. Other campaigns have not been so lucky. When abusive litigation tactics succeed, there are no news reports announcing a successful settlement. The workers who have been intimidated into silence do not hold a press conference. Instead, if they are lucky enough not to have been fired, they continue work in the shadows, facing the same low pay and poor working conditions that led them to organize in the first place.

A labor organizing privilege is not a magic bullet that will secure the rights of workers to organize and collectively bargain. Employers will continue to resist the efforts of their workers to organize. As long as abusive litigation tactics are effective anti-organizing tools, employers will continue to use them. The privilege does act as a shield, however, protecting workers' confidential communications with each other and with their representatives. Without the privilege, workers are defenseless against these tactics. The privilege does not ensure that workers will be able to exercise their rights, but it provides a necessary condition for them to do so.

303. B\&B Hospitality Grp., LLC v. ROC-NY, Case No. 115230/2010 (N.Y. Sup. Ct.).

304. Stipulation, B\&B Hospitality Grp., LLC v. ROC-NY, Case No. 115230/2010 (N.Y. Sup. Ct. Feb. 9, 2011).

305. Order Denying Motion to Dismiss, B\&B Hospitality Grp., LLC v. ROC-NY, Case No. 115230/2010 (N.Y. Sup. Ct. June 3, 2011).

306. The author was counsel for ROC-NY in $B \& B$ Hospitality Group v. ROC-NY, and much of the above account is based on personal recollection. 